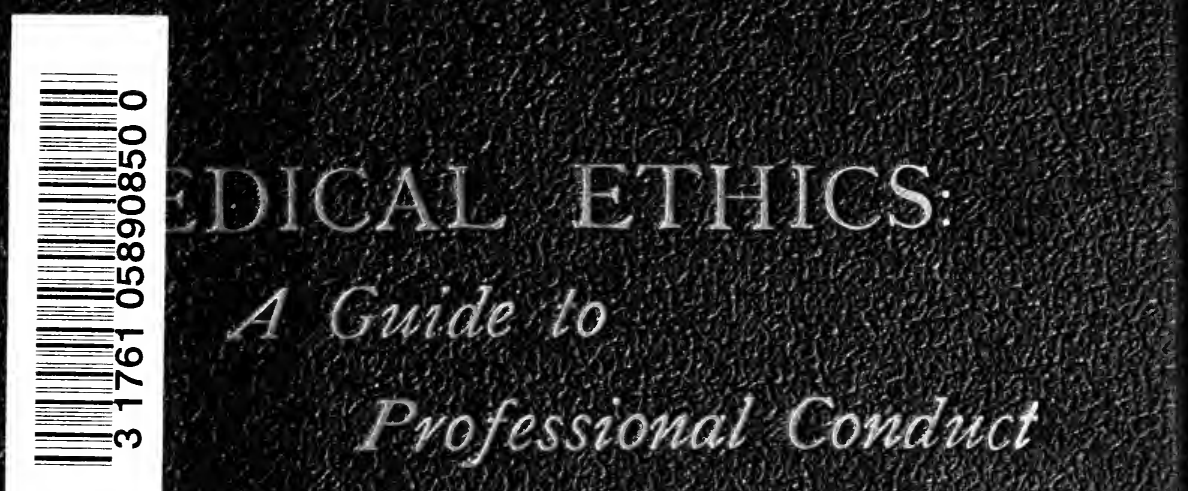

R

724

.S37

1902

GERSTEIN RT SAUNDBY M.D. EDIN. 


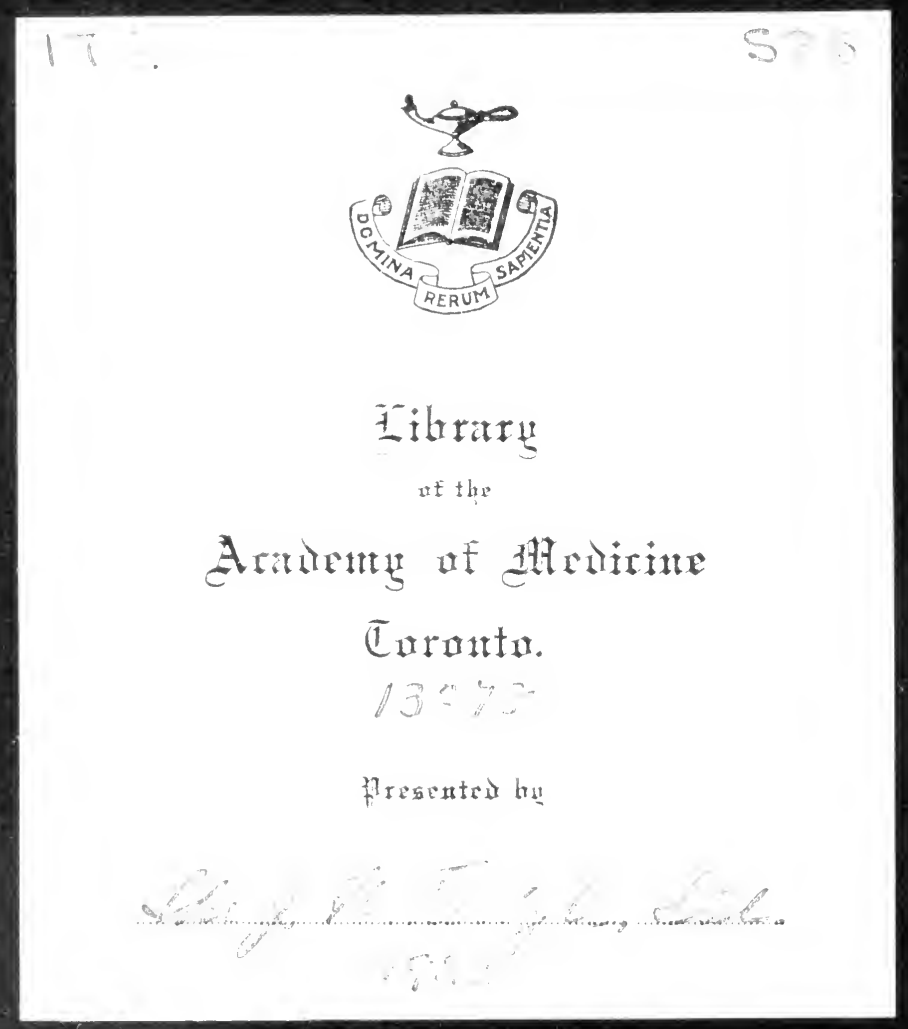

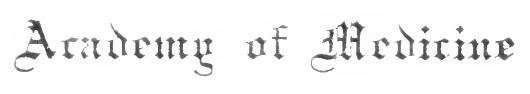

Tarantar.

$\int 3+\cdots$,

presented by

J. A. CAKVETH \& 60. MEDICAL BOOKS 




\section{MEDICAL ETHICS.}





\title{
MEDICAL ETHICS:
}

\author{
A GUIDE TO \\ PROFESSIONAL CONDUCT.
}

\author{
ROBERT SAUNDBY, M.D. EDIN., \\ Hon. LL.D. McGill., Hon. M.Sc. Birm., Filloze of the Roy. Coll. of Phys. of \\ Lond.; Vice-Pres., late Pres. of the Council of the Brit. Med. Assoc.; \\ Emenitus Sen. Pres. of the Roy. Med. Soc.; Fellow of the Roy. Hed. and \\ Chir. Soc.; Member of the Pathol. Soc of Lond.; Prof. of Medicine \\ in the Unir. of Bilm.; Phys, to the Gen. Hosp., Birm.; Consult. \\ Phys, to the Birm. and Widland Eye Hosp.; Consult. Phys. \\ to the Birm. and Miciland Hosp. for Women; Late \\ Examiner in Medicine to the Examining Board \\ for England.
}

BRISTOL: JOHN IVRIGHT \& CO.

London: Simpkin, Marshall, Hamilton, Kent \& Co., litd. 


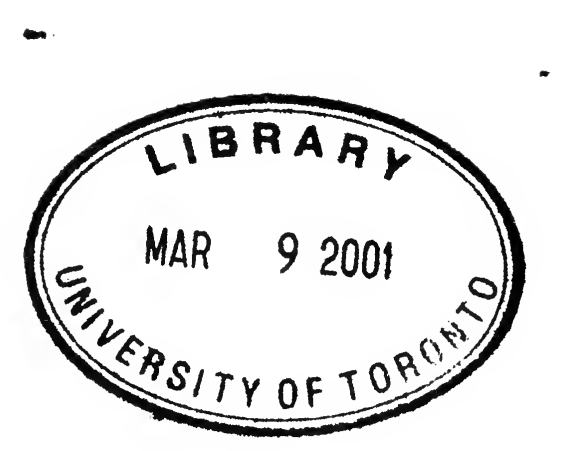




\section{PREFACE.}

THE subject of Medical Ethics is at present attracting great attention, not only in this country, but abroad. In Germany, we hear of the establishment of Medical Courts of Honour before which medical men may be brought for breaches of professional rules, and which possess the power of inflicting fines and other punishments. In France, a course of lectures on so-called "Medical Deontology" has been delivered during the past few years in Paris, under the semiofficial recognition of the Faculty of Medicine. The author has frequently heard students and young practitioners regret the absence of any similar instruction or guide in the United Kingdom. Undoubtedly one or two published codes exist, but they deal with only a part of the questions which constantly 
arise. The following pages are founded for the most part upon actual cases, and decisions which have been given in the leading medical journals during the past few years. It is therefore probable that other points than those treated in the text will arise, but the author prefers to leave these to be dealt with in future editions, rather than to quit the firm ground of actual fact.

Although they are in no way to be held accountable for any of the views expressed, the author desires to acknowledge the great assistance he has received from many friends who have kindly read the manuscript or proofs of this book. Among these he would especially mention Dr. H. Langley Browne, Sir Henry C. Burdett, K.C.B., Mr. T. Garrett Horder, Dr. Donald MacAlister, Mr. C. E. Mathews, Mr. M. A. Messiter, Mr. James Neal, Dr. James W. Russell, Dr. T. W. Thursfield, and Dr. Dawson Williams.

Birmingitai, June, I902. 


\section{TABLE OF CONTENTS.}

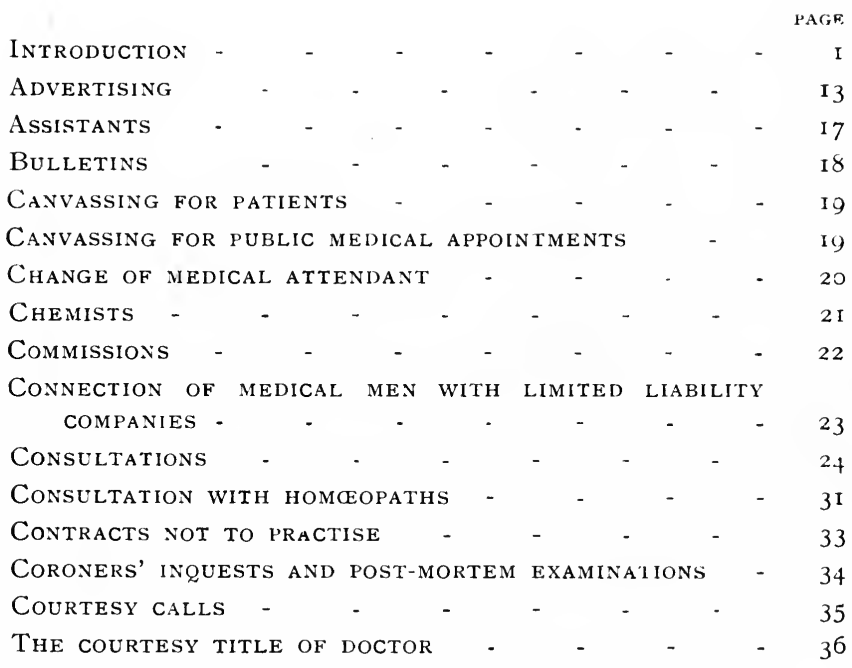

Courtesy attendance upon medical men, their wives,

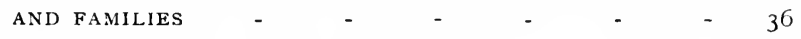


Fees from hospital patients - $\quad$ - $\quad$ - $\quad$ - $44^{6}$

Registration fees at hospitals - $\quad$ - $\quad$ - $\quad$ - 46

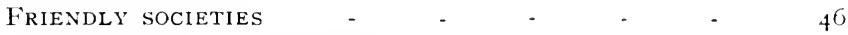

Gratis medical attendance - $\quad$ - $\quad$ - 47

INDUCTION OF PREMATURE LABOUR - $\quad$ - $\quad$ - $44^{8}$

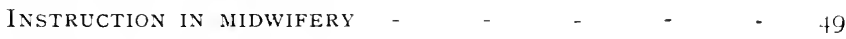

INSURANCE COMPANIES

LOCUM TENENS

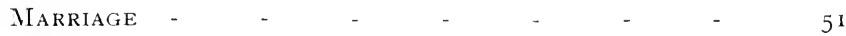

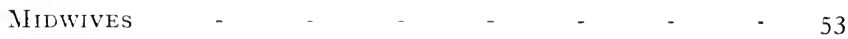

Medical officers of health $\quad$ - $\quad$ - $\quad$ - 53

MEDICAL OFFICERS OF ACCIDENT INSURANCE COMPANIES - . MEDICAL REFEREES OF RAILWAY CASES - $\quad$ - $\quad 54$

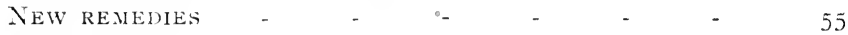

Operations - $\quad$ - $\quad$ - $\quad$ - $\quad$ -

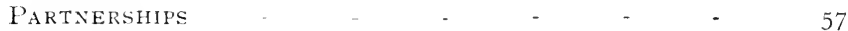

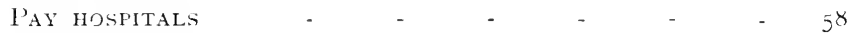

THE pRACTICE OF MDWIFERY BY STUDENTS - $\quad-60$

Prescriptions -

Patenting surgical instruments - - . 6 - 6 i

Payment of a substitute $\quad$ - $\quad$ - $\quad$ - $\quad$ - 62

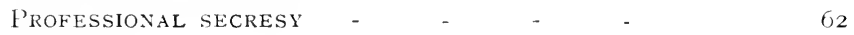

PROGNOSIS -

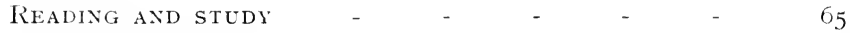

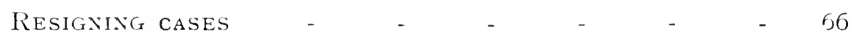

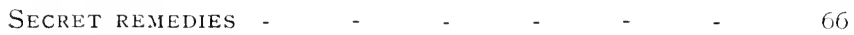

Trade testimonials and IUfFs - $\quad$ - $\quad-\quad-67$

UNDERSELLING

Vaccination and public vaccinators - $\quad$ - $\quad$ - 69

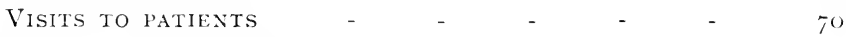

WitNesses IN COURTS OF LAW - - - $\quad$ - 70

APPENDIX 


\section{MEDICAL ETHICS:}

A Guide to Professional Conduct.

\section{INTRODUCTION.}

UNQUESTIONABLY during the last few years there has been a great awakening of interest in the subject of medical ethics, and an increased desire on the part of a large number of members of the medical profession to see a simple code of conduct established which may serve as a guide to the inexperienced, as well as a rule by which wrong-doers may be convicted. During two winter sessions, courses of lectures upon "déontologie médicale" have been delivered under the auspices of the Faculty of Medicine in Paris. These lectures are not official, but they have received semi-official recognition, and if successful it seems probable that they will in future form a part of medical education in France. Our medical 
newspapers week by week publish answers to correspondents who ask the advice of the editor upon various points of medical ethics and etiquette, and no one who has carefully watched this correspondence can fail to be struck with the sameness of the problems propounded. It has fallen to the lot of the author for a good many years to deal with such questions, and it is the experience thus acquired which has emboldened him to write this little book.

Apart from a few resolutions of the General Medical Council, the Royal College of Physicians of London, and some of the other licensing bodies, there are no rules by which a young medical practitioner who desires to do right may regulate his conduct; for although one or two books purporting to deal with medical ethics exist, they are not very satisfactory when guidance is sought upon particular points. It is not sufficient to say, as some people do, that medical ethics may be summed up in the Golden Rule, or that a man has only to behave like a gentleman; these are doubtless excellent principles, but there are numerous instances in which some definite guidance in their application is needed. Moreover, what was regarded as customary and even proper some years ago, has 
often come to be universally condemned, so that unless we suppose that our conception of Christianity and chivalry has undergone a complete revolution within the same period, it is quite clear that the above-named principles, though good in themselves, are scarcely adequate to the present purpose.

This change of opinion is abundantly illustrated in the matter of advertising. The sign which a medical man puts outside his house is of course an advertisement, and a few years ago it was a common thing to see this take the form of a red lamp and a large brass plate; now the red lamp is disappearing, and the brass plate is of quite modest dimensions; but, on the other hand, much undesirable advertising of a different kind has grown up. Some go so far as to publish an announcement of their names, qualifications, hours of consultation, and fees, in the advertisement columns of newspapers; others are content to print the same information on cards or hand-bills which are distributed in the neighbourhood where they seek to practise. But by far the largest part of modern advertising is of an indirect kind; every opportunity for gaining publicity is promptly seized, whether it be an application for a public appointment, 
a popular health lecture, or attendance upon a more or less prominent person. The universal existence of newspapers, and the shameless energy of reporters in quest of personal details, make it difficult for the most modest man to avoid being occasionally, against his will, the subject of a newspaper paragraph; but there can be little doubt that a great deal of the publicity accorded to certain members of the profession is not unsought. Newspaper advertising is condemned by the profession, and when cases are brought to their notice, even the licensing bodies feel compelled to interfere; but unless somebody undertakes the invidious duty of informer no notice is taken by them of the offence.

There are other questions which are quite modern, such as the relations of medical practitioners to unqualified persons, unregistered dentists, medical aid societies, and provident dispensaries. Probably each generation has its own difficulties, and presents its own problems, so that rules laid down now may in twenty-five years time be obsolete; nevertheless, such detailed rules as are formulated in the following pages are needed. It is not contended that they are infallibly right, but considerable care has been taken, 
by submitting them to a large number of experienced persons, to make them representative of the best professional opinion. Unfortunately, it has not always been possible to secure agreement; and under these circumstances the author has had to use his own judgment.

One of the most debated questions at the present time is the relation of medical practitioners to provident dispensaries, sick societies, and sick clubs. These, as is well known, are of various kinds. Some are branches of the great registered Friendly Societies; others are merely local organizations; in both cases they are based on principles of co-operation, self-help, and thrift. Others again are purely commercial undertakings, run for profit; and it is the incursion of this last element into the domain of the provision of medical attendance for the working classes, which has had the greatest share in the creation of the present strained relations. All with one exception work on the principle of a fixed annual payment by each member to the society, and an equally fixed payment from the society to the medical practitioner.

The complaints of medical men are that the rate of payment is too low, and that many of these societies admit to their membership 
or retain as members, persons who are quite able to pay ordinary medical fees. It is often asked that no one should be admitted as a member or allowed medical benefits whose income is above a certain wage limit; but this is refused by the societies, who say that such a rule would deprive them of some of their oldest and most valued members, and they do not agree that these well-to-do persons take advantage to any considerable extent of the medical benefits afforded. It does not appear that any question of medical ethics arises in connection with this dispute; but it has been maintained in some quarters that where a provident dispensary has no wage limit, the members of its staff are acting unethically in continuing in its service, although none of the great friendly societies has so far been willing even to consider the question; it therefore would seem hardly fair to condemn anyone for association with a provident dispensary merely because it has no wage limit. The attempts hitherto made to establish a wage limit have not proved successful, except in a few instances, and the medical profession would do well to turn its attention to the solution of this problem afforded by the plan of the National Deposit Friendly Society. This 
Society has no contract with its medical officers, but pays according to a published scale of fees. Any person may join the Society, but he has to find a medical practitioner willing to take him at the Society's rate, which he is not likely to be able to do if he is well off, although under the rules it may contribute pro tanto towards the payment of the doctor's bill.

The usual objection that is put forward against this plan is that the scale of payment is too low; but that is capable of amendment. The question is which affords fairer payment for work actually performed? A friendly critic, ignoring the growing importance of this Society, has suggested that this proposal is impracticable, and that the club system, if faulty, is indispensable. It has been said that unless medical men can get a good deal from club work they will not take the trouble to do it well, and that if it is to be split up no one will care about it. In Germany, under the State system of workmen's insurance, the workmen are free to go to any practitioner, who must see them for the fixed payment of a mark (which is equivalent to a shilling), yet it appears that those doctors who lay themselves out for this work get practically the whole of it, although there is nothing to 
prevent workmen going to anyone they please. It therefore seems reasonable to expect that similar results would follow in England, if this method of payment were to become generally established.

The subject of consultations has been dealt with at considerable length, as it seems especially desirable to clear up a good many points in the relations between general practitioners and consultants. The whole of the questions involved in this section have been very carefully studied, and submitted to representative consultants and general practitioners. There are, of course, extreme men, who claim that no one who has once been under their care, or towards whom they may claim to stand as family medical attendant, has the right to consult anyone else without their permission; but the public will not agree to this limitation of their liberty, and consultants refuse to be bound by such a rule; it should be added that most general practitioners are perfectly willing to admit that it is impracticable to insist upon this claim. On the other hand consultants owe a duty towards the medical attendants of persons who consult them, and this it is hoped is clearly laid down.

The position to be maintained by consultants towards homœopaths is one with which it 
requires some courage to deal. It seems to the author that the only sound rule is the one maintained, namely, that consultation is permissible between all duly qualified medical practitioners, and that the mere adoption of certain doctrines should not abrogate this fundamental principle. It must be allowed that homœopathic practitioners are, as a rule, as well educated, as honest, and as respectable a body of men as those who do not accept their doctrines. The Irish College of Surgeons goes so far as to exclude from professional relations even those who practise mesmerism; yet under its modern name of hypnotism, this is quite a recognised and reputable method of practice. Although we may not all of us agree as to its value, no one would go so far as to say that the practice of hypnotism should place a man outside the professional pale, and in this respect at least, it will be generally agreed that the Irish College goes too far. The author has obeyed the resolution of the Royal College of Physicians of London, of which he is a Fellow, by avoiding consultations with homœopaths; but he knows that there are some Fellows who are not so scrupulous; he doubts whether any good is effected by the resolution being retained, and would be very glad to see it rescinded. 
Professional secresy is a matter about which it would have been much more satisfactory to lay down an absolute rule, but our patients' secrets are often not secrets at all. In the case of prominent persons, the public insists upon being kept informed of the progress of the disease, while the acquaintances and friends of ordinary individuals are no less exigent; the doctor is besieged with questions which he has considerable difficuly, in parrying without giving offence or raising unfounded suspicions. He must recognise also that to a great extent the anxiety of such friends is reasonable, and should be satisfied, so long as he does not in any way sacrifice his patient's interest by doing so. The law compels the doctor to reveal his patients' secrets by the notification of disease; and in courts of law, unlike a solicitor, he is not allowed to plea: privilege, and must state all he knows. It is not at all an uncommon occurrence for a doctor to be addressed by a perfect stranger with enquiries about a patient under his care, but no one would think of asking such questions of a solicitor, respecting an unfortunate man whose affairs were embarrassed. It should $\mathrm{b}$ : unnecessary to insist more than has been done in the text upon the impropriety of gossiping about our patients and their ailments, which is 
of course a highly improper and foolish proceeding.

Objections have been made to the paragraph in which it is recognised that a medical practitioner may go to the assistance of a midwife, and its omission has been suggested; but there are very good reasons why this would not be right. Midwives exist, and are in practice all over the country; their education is improving, and their utility is being recognised more and more by the public and also by the medical profession. In country districts midwives are encouraged to settle, and country practitioners who have long distances to go, are very glad to have their time and night's rest spared by such assistance. If, as seems probable, the Midwives' Bill now before Parliament becomes law the status of registered midwives will be better defined. It is unreasonable to contend that medical practitioners should refuse to co-operate with them, or to suggest that such co-operation amounts to "covering." The midwife, in her proper place and under suitable regulation, is an established member of society; the medical profession should recognize this fact, and should unite to secure her better education, and to exclude from practice ignorant and drunken women.

It will, perhaps, serve no useful purpose to 
allude further to subjects discussed in the text, about which differences perhaps exist among us. It is hoped that the candid expression of opinion will, where it fails to carry conviction, at least give no offence, and that upon the vast majority of questions discussed the views put forward will be found to accord with the best feelings and the highest judgment of the profession. 


\section{MEDICAL ETHICS.}

\section{AdVERTISING.}

M EDICAL practitioners should not seek to 1 obtain practice by advertising themselves or their writings in lay publications, or by being parties to the publishing of paragraphs notifying their attendance upon prominent persons, or by sending to the press signed bulletins respecting such illnesses except in the case of Royalty (See Bulletins); or by permitting biographical notices with portraits of themselves to be published; or by publishing their testimonials, or by permitting parts of them to be published; or by circulating cards and handbills. It is also undesirable to write letters to the lay press advocating a particular line of treatment; or to publish pamphlets upon medical subjects for sale to the general public.

From a recent decision of the General Medical Council, it is plain that medical practitioners have not only themselves to avoid advertising, but they must take care that sick societies, clubs, 
and similar institutions with which they are connected do not in advertising make use of their names, or they will be held responsible.

In some health resorts, a list of local medical practitioners is published in the visitors' list. This may be defended on the ground of convenience, as equivalent to a directory, and the matter may be very well left to be decided locally, but the list must include all those in practice in the place.

It is not desirable to announce lectures to medical students by placing handbills in shop windows, as was formerly the custom at a famous medical school, or to advertise them in lay newspapers; moreover the advertisements of health lectures, and St. John's Ambulance lectures, should be carefully supervised, as many of these advertisements are objectionable in form, and call forth strong protests from the profession.

It is undesirable that medical schools or hospitals should publish lists of their medical staffs in advertisements in lay newspapers, or in appeals for subscriptions, or should give the private addresses of members of their medical staffs in their annual reports.

Medical practitioners should not advertise a scale of fees upon their doors or windows, or print their names and qualifications upon temperature charts, prescription papers, labels or 
bottles, except so far as may be required by the clause of the Pharmacy Act regulating the sale of poisons, which orders the bottle to be distinctly labelled with the name and address of the person dispensing the poison. ${ }^{*}$

Medical practitioners should not advertise under cover of announcing partnership arrangements, or their dissolution by death or otherwise, or the purchase of a practice, or change of address. Circulars may be sent only to bon $\hat{a}$ fide patients. It is not desirable to send printed copies of the new comer's testimonials, even to bon $\hat{a}$ fide patients of the practice.

The advertisements under the heading of Fashionable Intelligence, in which one reads that "Dr. So-and-so has returned to 555, Harpole Street," are defended on the score of convenience, but provoke much adverse comment. The practice is bad, and is the more objectionable as it is followed by leading practitioners; they thereby set a bad example to their less fortunate

* "Nothing contained in Section 17 of the said recited Act shall apply to any medicine supplied by a legally qualified medical practitioner to his patient, or dispensed by any person registered under the said Act, provided such medicine be distinctly labelled with the name and address of the seller, and the ingredients thereof be entered, with the name of the person to whom it is sold or delivered, in a book to be kept by the seller for that purpose."-32 and 33 Vict. cap. cxvii. sec. 3 . 
brethren, whose temptations to depart from the strict path of professional rectitude in the matter of advertising are so much greater.

Medical practitioners should not as a rule affix name plates upon houses where they have no tenancy; but it is recognised that in widespreading districts it is permissible and in fact necessary that medical practitioners should be able to indicate houses where messages may be left for them, or where under certain circumstances they can see patients. It is not desirable that the house selected should be a chemist's shop.

A medical practitioner should not allow his name to be used in the advertisements of a nurse.

Books dealing with the pathology or treatment of disease should not be advertised in lay newspapers, or be sent to them for review.

Medical practitioners should not allow their names to be used in trade advertisements, or permit the publication of testimonials signed by them in favour of drugs, dietetic specialities, wines, or other articles.

While medical practitioners, like other persons, are entitled to the convenience of having their names in post office and telephone directories, they should not advertise in them by indicating their particular line of practice or hours of 
consultation (e.g., "Dr. Smith, Ear and Throat specialist, consultations Io to I 2 ").

It is generally admitted that medical practitioners may advertise in the lay press for resident patients, and if they are proprietors of lunatic asylums, homes for inebriates sanatoria for phthisis, or hydros, they may advertise these institutions; but the name of the medical man should not appear in these advertisements. The practice of publishing the name of the medical proprietor or resident physician of hydros in advertisements at Railway Stations and in Railway Guides is most objectionable.

\section{Assistants.}

Assistants to medical practitioners must be registered, except in the case of bon $\hat{a}$ fide medical students, who may see cases under the direct supervision of their principals.

Unqualified persons may be employed as dispensers, there being no legal obligation for them to possess even a pharmaceutical qualification, as the principal is supposed to take the whole responsibility. It is, however, highly desirable that medical practitioners should not employ unqualified and untrained persons to dispense for them when not under their direct supervision.

Unqualified dispensers must not be left in charge of shops where poisons are sold to the 
public. (See Appendix, "Regulations of the General Medical Council," No. IV.)

Qualified assistants must make their own terms on engagement, as apart from special arrangement they can claim only a week's notice or week's salary on dismissal, and are liable to summary dismissal for neglect of duty, absence without leave, overstaying leave of absence, or disobeying orders. They have no claim to any fees received by them in connection with the practice, or for giving evidence in court or at inquests, or for post mortem examinations, or for extracting teeth, or for any other work connected with the practice.

It should not be forgotten that the qualities which make a good assistant go to make a good partner; and that the many petty annoyances which an assistant has to bear, differ only in degree or in kind from those which all medical practitioners have to expect, and must discipline themselves to endure.

\section{Bulletins.}

The public demands information respecting the illnesses of prominent persons, and custom has sanctioned the publication of signed bulletins in the case of members of the Royal Family. At the time of the death of George IV. daily bulletins were signed by Sir Henry Halford and 
Sir Matthew Tierney. While the custom must be allowed in the case of Royalty, it is not desirable to extend it to other persons ; information regarding their illnesses should be given to the press by the family, but the statement should neither be signed by nor contain the names of the medical practitioners in attendance.

\section{CANVASsing For Patients.}

The following resolution was passed by the General Medical Council on June 6th, I899: "That the Council strongly disapproves of medical practitioners associating themselves with medical aid associations by which systematic advertising and canvassing for the purpose of procuring patients are practised." That the Council does not intend this resolution to be a dead letter has been shown by its action in two cases which have been brought before it.

Canvassing is equally reprehensible where the agents are either collectors for private medical clubs, midwives or monthly nurses.

Any sort of canvassing and touting for patients is greatly to be deprecated.

Canvassing for Public Medical Appointments.

Where the number of electors to a public medical appointment is large, the methods used 
during canvassing by candidates and their friends are often most objectionable.

Medical practitioners should exert all their influence to secure that such elections should be in the hands of a comparatively small committee.

Testimonials should not be advertised or distributed to others than the members of the electo:ate, and there should be no use of posters or handbills in favour of any candidate.

\section{Change of Medical Attendant.}

It must be conceded that every patient has the right to select his or her own medical attendant, and to change him at will. Therefore, provided certain conditions are fulfilled, one medical practitioner may succeed another in attendance upon any person or case, without affording ground for complaint.

The most essential condition is that the former medical attendant should be courteously informed that his services are no longer required: and it is the duty of every medical practitioner, when called upon to supersede a colleague, to take care that this act of courtesy has been performed.

The other condition is that no one is at liberty to take over the treatment of a case to which he has been called in consultation, or where he has acted as a substitute for the ordinary medical 
attendant, except with the assent of the latter.

Where a patient puts himself under the care of a new medical attendant, the latter has no right to demand from the former medical attendant details of the treatment followed by him; but it would often be perfectly proper on the one hand to ask for, and on the other to supply, such information.

\section{Chemists.}

Medical practitioners should be careful, in their relations with chemists, not to enter into any arrangement which may savour of profit-sharing. They must not accept a commission on medicines dispensed; and still less should they render any consideration to the chemist in return for patients recommended by him.

Under no circumstances should a medical practitioner meet a chemist in consultation, or correspond with him respecting the treatment of a case, for to do so would be "covering," and would expose him to serious penalties. (See Covering.)

Some chemists act as opticians, and are in the habit of sending patients to medical practitioners to have atropine put into their eyes. This is an unsatisfactory practice, and one which cannot be recommended. In any case the medical practitioner must satisfy himself that there is 
nothing in the condition of the eyes to contraindicate the employment of atropine, and for such attendance he must be paid by the patient. If any injury follows the use of the drug, the medical practitioner and not the chemist will be held responsible.*

\section{Commissions.}

Medical practitioners should not receive commissions from tradespeople in return for recommending them or their wares, or from dentists for recommending patients, nor should they pay commissions to hotel proprietors, lodging-house keepers, monthly nurses, midwives, or others, for introductions to cases.

A consultant should not share his fee with the medical attendant, nor should the latter make such a demand. This custom does not exist in England, but prevails to a considerable extent in France, and although condemned there, it seems very difficult to eradicate.

Commission should not be paid by proprietors of lunatic asylums to relieving officers or other public officials who may send them patients, as such commission is in the nature of a bribe.

Commissions may be paid to agencies for introducing resident patients, but no medical practitioner should receive a commission for

* " The above applies equally to opticians, not being chemists, who apply to medical practitioners to instil atropine for them." 
recommending a patient to a colleague; or from hotels, boarding houses, lunatic asylums, sanatoria, or touring agents; or for any service where his whole duty is to his patient, from whom alone he should accept remuneration.

Commission may be accepted from Insurance Companies, but the medical practitioner must not act as medical examiner for cases introduced by him.

Connection of Medical Men with Limited LIABILITY COMPANIES.

The Royal College of Physicians of London, on October $25^{\text {th, }}$ I 888 , passed the following resolution: "That it is undesirable that any Fellow or Member of the College should be officially connected with any company having for its object the treatment of disease for profit." It is not easy to see why the prohibition was not extended to Licentiates.

Not very long ago the College manifested its disapproval of a Fellow occupying a seat upon the Board of a company interested in a dietetic specialty. A good rule seems to be that practising members of the medical profession should not be connected with any company having for its object the treatment of disease for profit, or be interested in the sale of anything which it may be their professional duty to recommend to their patients. 


\section{Consultations.}

The wish of patients to obtain further advice is natural, and should not only be acceded to cheerfully, but in many cases may be anticipated. It is not derogatory to any practitioner's knowledge or skill to have to seek special aid, as the domain of medical science has become far too wide to be embraced by any single human intelligence.

It is the imperative duty of the medical attendant to suggest the propriety of a consultation, when there is danger of loss of life or of the function of an important organ, and the same rule holds good before performing an operation involving similar risks, unless it is one of immediate urgency.

The consultant may be selected by the patient, or by the patient's family, or by the medical attendant. The medical attendant is not justified in refusing to meet a consultant selected by the family; but if, as may be the case, the one so selected has no special knowledge of the class of disease in question, this may be pointed out.

The medical attendant should not definitely refuse to meet any duly qualified practitioner except for grave reasons, as such a refusal is a serious professional affront.

Consultations are usually held either at the house of the patient or at that of the consultant. 
It is customary to allow the consultant to fix the time of the consultation, but in writing to him a convenient hour may quite properly be indicated. $\therefore$ It is incumbent upon both parties to a consultation to endeavour to be as punctual as possible. If the consultant finds the usual medical attendant does not keep the appointment, he may, after waiting a reasonable time, see the patient, and leave his conclusions in writing in a closed envelope.

Before seeing the patient the medical attendant should give the consultant a brief history of the case, unless, as may happen under exceptional circumstances, there are reasons for desiring that the consultant should form his own opinion and obtain the information for himself.

On entering the patient's room the medical attendant should precede the consultant, and introduce him if necessary to the patient.

It is desirable for the consultant while questioning and examining the patient, to say as little as possible to indicate the result of the examination. After the examination, the parties to the consultation should go into another room and discuss the diagnosis, prognosis, and treatment; it is well to record in writing the details of the treatment agreed upon.

If the parties to a consultation should be unable to agree on the management of the 
case, the friends must be informed of the difference of opinion. It is then open to them to seek further advice, either (as is preferable) in consultation with those already in attendance, or with the medical attendant only. Such a difficulty rarely occurs, as the consultant is generally selected for his special knowledge, and therefore it is usual to accept his opinion and allow him to direct the treatment. Even where the medical attendant may have doubts, he would not be justified in opposing the suggested treatment unless it involved great risks to his patient; that is to say, his opposition must be based upon the interests of his patient, and not upon his regard for his own opinion.

In the subsequent interview with the friends, the consultant should explain the conclusions arrived at, and may answer any questions put to him. It is very usual to visit the patient again before leaving, more with the intention of saying a few encouraging words, than to make a formal statement, but if questioned the consultant may tell the patient so much as he thinks it desirable for him to know.

If the friends of the patient desire it, they may make an appointment for the consultant's next visit before he leaves, but the consultant should not ask them to allow him to see the patient again, 
unless the medical attendant desires it and has requested him to do so. Under ordinary circumstances the arrangements for a future consultation may be left to be determined by the progress of the case.

The consultant should not inquire after the patient by calling upon him, or by letter, except through the medical attendant; nor should the consultant allow the patient's friends to call upon him, or discuss the case with them, in the absence of the medical attendant.

The consultant must under no circumstances take sole charge of a case seen by him in consultation. This restriction holds good only for the particular illness, and does not extend to future illnesses. (See Change of Medical Attendant.)

Consultation often takes place between general practitioners, especially in country districts; and he who is called in consultation must follow the etiquette and accept all the obligations of a consultant; he must under no circumstances supersede the medical attendant in the treatment of the case.

Consultants are in the habit of seeing patients in their consulting rooms, either $(a)$ in consultation with the patient's medical attendant; (b) at the request of the medical attendant, who should send a letter giving a statement of the case ; 
or (c) at the desire of the patient, who may have no medical attendant, or who although under treatment, yet desires to obtain an independent opinion upon his case.

Under ( $a$ the consultation does not differ from that just described at the house of the patient; under (b) the consultant should put his conclusions in writing, and enclose a prescription to the medical attendant, but he is at liberty to answer any questions addressed to him by the patient; under (c) if a medical practitioner is in attendance, the consultant should point out the desirability of his being allowed to communicate with him, and if this permission is given should act as in the former case; but if the patient refuses to allow him to do so, the consultant has no right to disregard the patient's wishes.

As the statements of patients are frequently inaccurate, probably in most cases from ignorance, medical practitioners should be careful how they accept them when they reflect upon a colleague, or put his sayings or doings in an unfavourable light.

It is greatly to be desired that the medical attendant should, in his statement of the case, mention any opinions to which he may have committed himself, so that the consultant may not unwittingly contradict him. 
If the patient obviously ought to be treated in bed, the consultant should insist on the cooperation of the medical attendant, or if the latter has become for any reason quite unacceptable, he must point out that he cannot take sole charge of the case, and that another medical attendant must be obtained.

If the patient is anxious not to quarrel with his family doctor, but equally determined not to remain under his care during the present illness (e.g., syphilis), the consultant may recommend the patient to go into a nursing home, or to a health resort, where he can be under the care of a local practitioner, to whom the consultant can write explaining the case and giving any necessary directions.

A patient may be sent by his medical attendant to a consultant: (I) For him to operate or carry out a special plan of treatment, such as the Weir-Mitchell treatment, when the consultant must take all responsibility and have full control ; (2) Or for him to advise as to the propriety of an operation or of a certain line of treatment, when the consultant should send the patient back, and give the medical attendant a written opinion.

The rule has been already laid down that a consultation may be held with any duly qualified practitioner, that is to say, with one possessing 
qualifications registered or registrable in the United Kingdom; but this rule would not forbid consultation with a foreign physician who possessed proper qualifications in his own country, and who was called in consultation or happened to be visiting here. In fact, the utmost professional courtesy should be extended to foreign physicians of good repute both at home and abroad.

In British colonies and in foreign countries it may be necessary to meet in consultation practitioners whose qualifications are not well defined; but it is impossible to lay down a rule which shall be applicable to all circumstances of distant or less civilised or sparsely populated countries. Before I 858 a large number of the general practitioners in England were what would now be called unqualified.

Medical practitioners, especially consultants, are often consulted by letter; but it is not desirable to give an opinion or to undertake the treatment of any person who has not been seen and examined, although where a statement of the case is forwarded by the medical attendant the consultant need not refuse to give such assistance as he can, where circumstances may render it quite impossible for a personal interview to take place.

Medical practitioners may be called in by 
midwives, but a midwife possesses no knowledge which can make her a party to a consultation. Under such circumstances she should be treated with courtesy, but the medical practitioner should take full charge of the case, and regard the midwife rather as an assistant than as a colleague.

Consultation with Homcopaths.

It is the custom for consulting surgeons to meet homœopaths in consultation. The reason assigned for this is that homœopathic doctrines do not extend to surgical methods; but it might be with equal force argued that if a homœopath seeks the assistance of a non-sectarian physician in consultation, it is because he is willing to waive his personal opinions upon the question of treatment. If there is any moral obliquity, as suggested by the resolution of the Royal College of Physicians of London (see Appendix, page 78 ), in "The assumption or acceptance by members of the profession of designations implyng the adoption of special modes of treatment," which in the opinion of the College justified it in calling upon its fellows, members, and licentiates to "discountenance" such persons, then it must be admitted that surgeons are as much bound as physicians not to meet them in consultation. It is, however, a question whether this 
decision of the College of Physicians should not be reconsidered, as if those who meet in consultation find themselves unable to agree, there are well established rules to meet the case. A homœopath may violate the rules of medical ethics by his conduct, for which he may be made answerable; but his adhesion to a therapeutic proposition, however absurd we may deem it, should not, by itself, justify his professional excommunication.

It should be remembered that the medical profession is not a sect, and that it has no creed. Properly qualified medical men should be admitted to all professional corporations and societies, and should be accorded every professional courtesy, irrespective of the theories held by them. There may, and always will be, differences of opinion, and we may sometimes entertain strong views as to the wisdom of certain modes of practice; but "boycotting" for these differences is unworthy of a profession based upon natural science, in which conflicts of opinion are the inevitable condition of progress; moreover the Licensing Bodies, and the General Medical Council, are prohibited from proceeding against any member of the medical profession upon such grounds.*

* "In case it shall appear to the General Council that an Attempt has been made by any Body, entitled under this 
Contracts not to Practise.

A medical practitioner who has sold a practice, or has for any other reason entered into a contract not to practise within a particular area, should be careful not to trifle with the terms of his undertaking, by seeing old patients from that area, even although his residence is situated outside the prescribed limits, or by going into the district to see patients gratis. The usual terms of the Restriction Clause should be made more explicit, as it has happened that patients have gone regularly to see the vendor at a place outside the area, thus breaking the contract in spirit, if not in letter. The facility of communications in these days renders such evasions quite easy, even though the vendor may live at a considerable distance.

On the other hand, it would not be a violation

Act to grant Qualifications, to impose upon any Candidate offering himself for Examination an Obligation to adopt or refrain from adopting the Practice of any particular Theory of Medicine or Surgery, as a Test or Condition of admitting him to Examination or of granting a Certificate, it shall be lawful for the said Council to represent the same to $\mathrm{Her}$ Majesty's Most Honourable Privy Council, and the said Privy Council may thereupon issue an Injunction to such Body so acting; directing them to desist from such Practice; and in the event of their not complying therewith, then to order that such Body shall cease to have the Power of conferring any Right to be registered under this Act so long as they shall continue such Practice." -21 and 22 Vict., caf. xc., sect. 23 . 
of the general terms of such a contract to see a patient in consultation within the prescribed limits, or to go there in pursuance of the duties of a public medical appointment, such as medical officer of health, medical inspector, or public vaccinator, so long as none of these offices was included in the practice he had contracted to renounce.

\section{Coroners' Inquests, ANd POSt-hortei ExaMINATIONS.}

When a medical practitioner receives a coroner's order to make or assist in making a post-mortem examination, he is bound to obey the summons, and should use due diligence in performing this duty. Cases have occurred in which the medical practitioner has made only a superficial examination of the body, yet at the inquest has sworn to the particular condition of each organ. Some practitioners, having found what seems to them the cause of death in one of the cavities of the body, do not consider themselves obliged to open the others; but this should not be omitted, and some coroners rightly print on the order, "a post-mortem examination of the body, including the viscera of the head, chest, and abdomen." The coroner should take care to secure an impartial person in those cases where he may 
have good reason for not desiring to entrust the examination to the medical attendant upon the deceased person, as very scandalous evidence has been given when the examination has fallen into the hands of a professional rival.

In all cases where a practitioner is called to make a post-mortem examination of a case which has been under the care of another medical man, whose conduct or professional skill may be called in question, it is his duty to give him the opportunity of being present, and to allow him, should he desire it, to be accompanied by a pathological expert. In making his report and in giving evidence, he should tell the truth without straining the facts either for or against his brother practitioner; but if any doubt exists the latter should have the benefit of it.

In civil cases care must be taken to see that both sides are represented, or have had an opportunity of being represented, before the body is opened; otherwise the facts disclosed may be disputed, and their value will be certainly diminished, as the failure to give notice to the other side will be considered to be unfair towards them.

\section{Courtesy Calls.}

New comers are expected to call upon all old resident practitioners, and these should return the call within a reasonable time. In large 
cities it is impossible to follow this custom in its entirety, and it is sufficient for the new comer to call upon his medical neighbours within a radius of say half a mile.

The rule applies to medical women as well as to medical men, as it is good for all medical practitioners to know one another, and to be on friendly terms.

If there is a medical society in the place, the new comer should seek to become a member as soon as possible.

\section{Courtesy Title OF Doctor.}

Any member of the medical profession may be called "Dr." by courtesy, but no one should assume the title by placing it on his door-plate or visiting card who does not possess the M.D. or M.B. degree of a university. It is an undoubted grievance of English medical students, that their opportunities for obtaining University degrees have been in the past very inferior to those enjoyed in other countries; but the recent development of provincial universities, and the reorganization of the London University, will in time remove this anomaly.

Courtesy Attendance upon Medical Men, Their Wives, AND FaMilies.

Medical practitioners have no right to the 
gratuitous services of their colleagues, but it is a salutary custom in the profession not to make any charge for such services among neighbours and friends.

Consultants usually refuse to accept any fees for their services, and often travel considerable distances and perform serious operations upon medical colleagues and members of their families without payment; but no one has a right to expect this. Where the services involve a considerable sacrifice of time, the fee should be tendered unless the consultant has previously agreed to give his services for nothing.

It is unreasonable for medical practitioners to refuse to pay fees for members of their families who are taken ill away from home, or to pay the small medical fee demanded for each boy in a public school.

It is usual for the staff of a medical school to see medical students without fee; but this also is a courtesy, and not a right.

It is usual for doctors to refuse to accept fees from nurses, but here also the remission is merely an act of grace.

\section{COVERING.}

The professional association of a registered medical practitioner with an unqualified person is called "covering," and constitutes a very 
grave offence not only against medical ethics, but against the regulations of the General Medical Council. (See Appendix, "Regulations of General Medical Council,” No. I.)

\section{Dentists.}

Medical practitioners have no right to expect to be treated gratis by dentists, nor have dentists any claim for gratis services from the medical profession, but it is very common where a dentist and medical practitioner happen to be professional neighbours to reciprocate such services, neither is it in any way objectionable.

It would be objectionable for a dentist to attend the family of a medical man, in the hope that the medical man would in consequence send his patients to him; just as it would be objectionable for the medical man to attend the dentist gratuitously on similar grounds; but there is sufficient reason for friendly reciprocity $\mathrm{n}$ mutual personal services.

Medical practitioners must not associate themselves in practice with unregistered dentists. (See Appendix, "Regulations of General Medical Council,” No. II.)

\section{DISPENSARIES.}

It is undesirable for medical practitioners to practise except under their own names; they should not do so under the name of a Dispensary 
or Medical Institute; still less should they, under cover of such a name, seek to obtain patients by advertisement.

Medical practitioners should not join the staffs of dispensaries that are not controlled by properly constituted public bodies, and they must satisfy themselves that the rules of the profession respecting advertising, canvassing, and touting for practice are not and will not be violated by the managers, or they will justly be held responsible by their professional brethren. In too many cases this rule has in the past been violated, and the holders of these offices find themselves held in bondage by an organization whose acts they are unable to defend or to control, the only remedy left open to them being resignation, which in too many instances involves a pecuniary sacrifice which they are unable to make.

It might be better if no provident dispensary had a regular staff, but the committee should undertake to pay according to a fixed scale any medical practitioner selected by a member. It would rest with the practitioner chosen to accept the terms or not as he pleased.

\section{DOCTOR AND PATIENT.}

The public demands that the relation between a medical practitioner and his patient shall be not simply the purely commercial one of vendor 
and purchaser, but one of trust; as the health, future prospects, and even the life of the patient are committed to his care. It is important for medical practitioners to remember that the courts of law take this view of their position, and that they must be careful how they accept considerable presents of money or valuables from grateful patients. Such gifts, to be valid, must be made with the knowledge and consent of some independent person, the patient's legal adviser or a near relative 'IVhere this precaution is not taken, the Court may order the property to be refunded, even after the patient's death.

Medical practitioners in this country are seldom called upon to defend actions for malpractice, but at common law they are liable for the consequences of any failure to exercise due care and skill, and may even be prosecuted criminally for gross negligence. The greatest danger is incurred in connection with the sign. ing of lunacy certificates, as certain lunatics have shown themselves capable of the most litigious persecution of persons by whom they consider themselves to have been injured. The important point to bear in mind in signing a lunacy certificate is, that the certifier must be satisfied not only of the insanity of the person, but of the grounds that exist for sending him to an asylum. Mere eccentricity of conduct or peculiarities of 
temper, while exceedingly try ng to his family, may not be regarded by the jury as justifying restraint. On the other hand, if he be either suicidal or homicidal, that is, dangerous to himself or to other people, there is little fear but that the jury will support the certificate. Nevertheless, as even the successful defence of an action at law may be ruinous, if the plaintiff is not in a position to pay the costs, all prudent men should insure against such risks by joining a Medical Defence Society.

\section{“Doctors' Shops."}

The Fellows, Members, and Licentiates of the Royal Colleges of Physicians of London, Edinburgh, and Ireland, and the Fellows of the Royal Colleges of Surgeons of Edinburgh and of Ireland, and of the Faculty of Physicians and Surgeons of Glasgow, are prohibited from keeping open shops for the sale of drugs, etc. It is to be desired that every member of the medical profession should act in accordance with this rule, for it is not consonant with the claims of the medical profession that its members should be the trade rivals of the pharmacists, of whose competition in the matter of prescribing remedies they complain. (See Assistants, p. I7.)

DRUg Habits.

The moral, physical, and even social ruin 
which follows the abuse of alcohol, opium, chloral and cocaine, originally taken by medical advice, throws upon the medical profession a most serious responsibility. It is a question whether alcohol ought ever to be prescribed to women, and especially young women, for the relief of pain; and when ordered for other purposes, this should only be done after careful consideration. The use of narcotic drugs should always be supervised, and their administration retained in the doctor's hands. It is better not to prescribe the pure drug, but to give it in a mixture diluted and disguised, so that the patient does not know the exact dose he is getting. If the desired effect does not follow the use of the remedy in reasonable doses, it is preferable to try another drug rather than to permit increased doses at the wish of the patient.

In the presence of hopeless, incurable, or speedily fatal diseases, many of these precautions are unnecessary, and under such circumstances the free use of such a drug as opium may often be the only means of affording the relief which it is our duty to procure.

\section{EMergency Calls.}

There is a wide-spread opinion among the public that a medical practitioner is bound to 
go when summoned to a case, but there is no such legal obligation. Nevertheless, to the honour of the medical profession, a summons is rarely left unheeded.

It is an injustice to the medical practitioner that the person summoning him is not necessarily responsible for his fee, which must be recovered from the patient, who may be unable to pay. It often happens that messengers go in several directions, and that in consequence more than one doctor arrives upon the scene; by general consent, it is recognised that the first comer has the right to attend the case, subject to prior claims (e.g., that the patient already has a medical attendant), but the others may fairly ask to be paid for their trouble, although in many cases it is useless to press this claim.

\section{EMPloyers' Liability.}

Medical practitioners must remember that when consulted by a workman their first duty is to him, and not to his employer, and that they have no right to furnish information to the employer without the workman's consent

On the other hand, if the workman is sent for examination by his employer, the medical practitioner may report to the employer upon the case, provided that the workman fully 
understands the conditions under which the examination has been made.

Under the Workmen's Compensation Act, a workman must attend at the consulting rooms of the medical practitioner selected by the employer, unless, in the opinion of his own medical attendant, he is unable to travel. (See 60 and 6 I Victoria, cap. 37, Schedule I, section I I.)

When a medical practitioner proposes to visit a workman in order to make an examination on behalf of an employer, he should give notice to the workman of the intended visit, and suggest the desirability of his medical attendant being present at the examination.

When consulted about an injury alleged to be the result of an accident, it is not the duty of the medical practitioner to ascertain whether the accident did take place, or to endeavour to define what constitutes an accident. Both these questions may be left for the Court to determine. He is asked to say whether, supposing certain events constituting the alleged accident to have occurred, the patient's condition in whole or in part is the result of such accident; he will be asked to define as nearly as possible the extent to which the accident is responsible for the patient's present condition, and to state the extent of the injury or incapacity 
resulting from the accident, its effect upon the injured person's health, prospects of earning his living, and the duration of his life.

According to the laws of most hospitals, the visiting and resident staff are compelled to give without payment all necessary certificates to patients. Where fees are payable, as under the Workmen's Compensation Act, it is desirable that a special arrangement should be made. The signer of the certificate has a primâ facie claim to the fees, and this should be conceded by the hospital authorities; but the matter is one for mutual arrangement, as in the case of a resident, he may be paid a salary calculated to cover all such incidental sources of income.

\section{EXPERIMENTS ON ANIMALS.}

It is justifiable to seek to throw light upon obscure questions in the nature and treatment of disease by experiments upon animals, but all possible care must be taken to inflict no avoidable pain or suffering, either by the performance of operations which are unnecessary or not well thought out, or by the neglect of precautions by which the distress of the animal may be alleviated or prevented. No person can legally make such experiments unless licensed by the Home Secretary, and in a licensed place.

Experiments on Patients. (See New Remedies). 


\section{Fees from Hospital Patients.}

No fees should be taken from hospital patients, and if well-to-do persons come to the hospital they should be sent away; they should not be told to attend at the officer's private residence, nor should he see private patients at the hospital, or in any way mix up his paid with his charitable work.

\section{Fees (Registration) at Hospitals.}

The medical profession should not countenance the prevalent practice of making hospital patients pay a registration fee. These fees, which vary in amount, are regarded as payment for the treatment received, and encourage the worst forms of hospital abuse. It is permissible to charge those who can afford to pay for maintenance, medicines or appliances, but this should be made clear to them, and they should pay only for what they receive. (See Pay Hospitals, p. 58.)

FRIENDLY SOCIETIES.

Medical practitioners must not accept office under Friendly Societies or Medical Aid Associations, without having satisfied themselves that the rules and methods of administration do not conflict with professional opinion and the decisions of the General Medical Council respecting advertising, canvassing, and touting for patients. (See Appendix, p. 75.) 
The relations of the medical profession to Provident Sick Societies have become strained, and would be greatly improved if the Societies would throw their work open to any medical practitioner selected by the patient, who is willing to accept the Society's scale of payment. By the adoption of this rule the burning question of wage limit would be got rid of, as each member would have to find a medical attendant willing to accept him at the Society's rate, and it would be open to any practitioner to refuse to see well-to-do persons upon inadequate terms.

\section{Gratis Medical Attendance.}

The clergy, as a class, have no right to medical attendance without payment, and the custom is falling into disuse. (See Courtesy Attendance, p. 36.)

Medical practitioners should only forego their fees to those persons who are unable to pay, and should refuse to recognise any other grounds for the concession.

Unquestionably, patients may be attended gratis from the very best motives, but the proceeding is open to very great abuse. It may be laid down as a rule that no one is justified in seeing a large number of gratis patients. Such cases should be exceptional, and there should be special reasons to justify the departure from the rule in each instance. 
It is quite right to see another man's patient for nothing, when acting as his substitute, but it is quite wrong to do so when by this means we take the bread out of his mouth, and prevent him from doing work for which he would be paid.

Medical practitioners may take part in charitable work by attending patients in institutions without payment, as the objects of such institutions are generally by common consent admitted to be good and the work laudable. If there is any doubt about the object pursued, or the methods employed, a medical practitioner invited to co-operate must carefully consider his position, as the mere name of charity must not be allowed to justify all things.

Homceopaths. See Consultation with Homocopaths.)

Hospitals (See Pay Hospitals).

Induction of Premature Labour.

By the laws of all civilised and Christian countries, the destruction of the living product of conception is punished as a crime, and public opinion condemns the practice as wrong-doing. Nevertheless it is well known that medical practitioners more or less frequently 
undertake proceedings designed to have this effect, and the question is-Under what circumstances is it justifiable to relax the stricter dictates of law and morality upon this subject? There is reason to believe that some laxity exists in the principles of some members of the medical profession in regard to this question, and that the gravity of the subject is imperfectly appreciated by them. Danger to the health of the mother is held by some to justify interference; a rule which is capable of such a liberal interpretation, that an inopportune pregnancy might always be interrupted upon this plea.

Before inducing premature labour, the propriety of the proceeding should, whenever possible, be confirmed by a second opinion. It should be clearly recognised that such proceedings are only sanctioned in the presence of grave danger to the life of the mother; and where the fœtus is viable, the operation selected should be, wherever possible, one which may preserve both lives.

\section{INSTRUCTION IN MIDWIFERY.}

It is competent for any duly qualified medical practitioner to give instruction in midwifery to medical students, or to midwives, but it is better that this training should be left in the hands of recognised institutions. 
Insurance CoMpanies.

Medical practitioners should not answer enquiries addressed to them by insurance companies respecting a person who may have consulted them, without having obtained the patient's consent, which, if pssoible, should be in writing.

\section{LoCUM TENENS.}

It is the obvious duty of any one acting as a substitute for another person, whether paid or unpaid, to consider that person's interests as his own, and to take no advantage of his temporary

- position to that person's prejudice; therefore, when a medical practitioner is asked to see a patient during the absence of a colleague, he should do his best for the patient, but do nothing that will tend to injure his colleague's position, and he must absolutely refuse to supersede him, even though requested to do so.

He has a right to be paid for his services, but it is often neighbourly to forego the claim.

A locum tenens who is paid to take charge of a practice during the absence of the principal from any cause, should regard himself as under an honourable obligation not to take advantage of his position by subsequently starting in practice in the neighbourhood. He may quite reasonably be asked to give an undertaking in legal form to this effect before being engaged. 
A locum tenens has no right to any fees received by him while acting in that capacity, even though these may be for giving evidence in law courts, and other work not strictly in the ordinary routine of practice.

But while he can claim no fees, he has on the other hand a right to be paid for his services, should such work involve detention after his time of service as locum tenens has expired.

\section{MARRIAGE.}

Medical practitioners are often consulted as to the propriety of marriage in the case of persons suffering from various diseases. It may be right to object to marriage for the following reasons: (I) Where the married state and its contingencies would prejudice the health and perhaps the life of the patient; (2) Where the patient is suffering from a disease which is more or less likely to be transmitted to the spouse or to the children; (3) Where the patient is suffering from, or is liable to suffer from, a disease which may prevent the performance of social duties; (4) Where the patient's life is uninsurable and an early death may interfere with the proper provision and care for the offspring of the marriage. These reasons are not of equal weight, and in each case the circumstances may vary. In the 
first class there are cases of advanced organic disease in which there can be no doubt that marriage should be forbidden, while in others the evil effect is more remote or merely contingent; but it would be the duty of the practitioner, while not absolutely forbidding the marriage, to point out its undesirability or the nature of the risk, as, for example, in a case of rickety pelvis. In the second class, where the patient is suffering from an infectious or contagious disease, marriage must be forbidden so long as any manifestations of the disease exist; but should the disease be such an one as hereditary diabetes, in which, while there is a risk of transmission, many, if not most of the children will in all probability escape, the fear of transmission alone should not forbid the marriage. Such a case might also come for consideration under the first and fourth classes, and the points under these heads would have to be considered in deciding as to the permissibility of the marriage. The third class refers to such diseases as epilepsy and recurrent mania, which are so terrible in themselves, as well as in their results, that medical practitioners should do their utmost to oppose the marriages of such persons. It is a horrible fact, but none the less true, that persons suffering from these conditions have married in consequence of 
medical advice. The fourth class is the least serious, as although it is of considerable importance that a parent should be able to bring up and provide for the offspring of marriage, it may be quite permissible to run this risk where money is not wanting.

\section{Medical Officers of Health.}

It is necessary in the interests of the public health that there should be a good understanding between medical officers of health and their medical neighbours.

In order to promote this, it is desirable that medical officers of health should visit patients under the care of other practitioners only after giving due notice, so that the usual medical attendant may, if he wishes, be present; and they should be exceedingly careful not to say or do anything, in the presence of the patient, to cast doubt upon the diagnosis or treatment of the case.

The same rule should apply to inspectors or nurses sent by the sanitary authority.

A medical officer of health in charge of an isolation hospital, is not justified in authorising a nurse in charge to refuse admission to cases sent to the hospital by a duly qualified practitioner unless she is satisfied of the correctness of the diagnosis. 
Medical OfFicers of ACCident Insurance Conpanies. Medical Referees of RaILway CAses.

Medical practitioners, acting in either of the above capacities, are often asked to visit persons who have made claims, with a view to report upon the nature and extent of the alleged injuries. In some of these cases there may be a suspicion of fraud, and, much more commonly, there is exaggeration; nevertheless, the medical examiner should behave with the utmost courtesy, and should altogether refuse to play the part of a detective. He should give notice of his visit, and request the presence of the patient's medical attendant. At the examination, he should ask for and willingly accept any information tendered to him by the latter, and should ask him to point out any symptoms or signs upon which his opinion of the case is founded.

The examination should be made with proper consideration for the patient, who should be treated with the same courtesy as at an ordinary consultation, and no unfavourable opinion should be expressed in the patient's presence, either as to his health or his honesty.

The medical examiner may make notes at the interview for the purpose of his report.

Medical examiners should try to be as impartial as possible, and aroid the appearance of being 
hostile to the patient and his medical adviser. In the interests of both parties it is generally desirable that an amicable settlement should be reached, and this is undoubtedly facilitated by a good understanding between the doctors concerned.

\section{Midwives.}

For consultations with midwives-See Consultations. Regarding arrangements with midwives--See Commissions.

\section{NEW REMEDIES.}

The application of new methods of treatment to patients, is an experiment to which we have no right to subject them without due cause. The general reason for such experiments is the impossibility of progress without the trial of new suggestions; but the particular grounds upon which we must base the use of a novel remedy, in a given case, are that the patient is suffering from a condition which has not been or cannot be relieved by the usual means, that there is reasonable prospect of the new remedy affording relief, and that it is harmless.

Nostrums. (See Secret Remedies.)

OPERATIONS.

Owing to the improvements in surgical 
technique, operations of all kinds are nowadays performed with great facility, and with comparatively small risk to the patient; but there is an uncomfortable impression abroad that, especially in certain departments of practice, operations are performed without adequate reason, and are by no means always to the physical advantage of the patient.

The responsibility of deciding whether an operation ought or ought not to be performed may often rest with the family medical attendant. He may fairly hesitate to decide such an important question, yet it is his duty to acquire sufficient knowledge to enable him to advise his patient and his patient's family. In deciding this point, the medical attendant must be guided solely by the welfare of his patient. Especially in the matter of exploratory incisions, he should not allow a desire to satisfy an otherwise laudable curiosity to outweigh this primary consideration.

No operation should be performed upon a patient unless its nature, risks, and consequences have been fully explained, if not to the patient, at least to the patient's friends.

The operator has the right to fix his own time, and to select his assistant and anæsthetist; the ordinary medical attendant has a right to be present, but cannot claim to act in either of these capacities, or to dress the wound subsequently. 


\section{PARTNERSHIPS.}

Partnerships in general practice have manifest and manifold advantages; but they have undoubtedly become less common of late years, and with their decline in number there has been a sensible weakening of the position of the general practitioner, especially in towns, an increase of competition, less hold upon patients, reduced incomes, greater strain in professional relations, harder work, more difficulty about holidays, and diminished value of practices, especially of their value in the case of death vacancies. Two, or still better three or four, medical practitioners, working together as partners, can do cne another's work in case of temporary illness or during holdiays, while they maintain the value of the practice, and can therefore afford, either on retirement or death vacancy, to pay a fair price, which should be according to the terms of the deed of partnership. Any disadvantages, such as the risk of a partner becoming incapacitated, or being unwilling to do his fair share of work, or in any other way proving a bad bargain, can be provided against by a properly drawn deed of partnership. On the other hand, the advantages so far outweigh any drawbacks, that it is much to be regretted that there is a manifest disinclination on the 
part of the present generation of practitioners to enter into these bonds. The apparent reason is that they are bonds, and that to a certain extent they do fetter liberty of action. But liberty may be purchased at far too high a rate. The qualities which enable men to work together amicably in partnership are of a kind worth cultivating. A good partner should be orderly, punctual, and diligent in the performance of the work he undertakes or that falls to his share; he should cultivate the most friendly professional relations with his partners, and guard against the slightest approach to jealousy, which seems to be the rock upon which partnerships generally come to grief.

\section{Patenting Surgical Instruments.}

It is not desirable that medical practitioners should patent surgical instruments in their own names, or allow instruments, apparatus, appliances, dressings, or drugs to be called by their names.

\section{PAY Hospitals.}

At several London hospitals, including two of the first rank, wards have been set apart for paying patients, and, as the system will probably grow, the proper attitude of the 
medical profession towards such departments of our hospitals demands consideration. The most familiar kind of pay hospital is the country Cottage Hospital, where it is the rule to charge so much a week, the patient being attended by his club doctor, and the payment coming directly or indirectly from a Club or Friendly Society. This system seems to be accepted by the medical profession, as while conferring considerable advantages upon the patients, it is not liable to abuse, for in any case the patient must make his own arrangement for medical attendance. So long as such a plan is followed no difficulty appears likely to arise; but it is quite clear that this system only partially fulfils the public demand, which is to secure the special skill to be found on hospital staffs at lower fees than those ordinarily charged to the public. It is said that the poor obtain these services for nothing, and that the rich can afford to pay for them, but that there is a large intermediate class which does not wish to go into hospital without payment, but is unable to pay the large fees demanded by specialists. The managers of hospitals have in some cases looked upon pay wards as a means of adding to the income of the hospital, and have competed directly with the private nursing homes; while in at least one case they have 
attempted to exploit the medical profession by seeking to compel the members of the staff to attend the patients admitted to the pay wards as part of their ordinary duty to the hospital. Such an arrangement is too manifestly unjust to require discussion, but the alternatives appear to be: (I) To allow the patients to select their own medical or surgical attendants and to pay them themiselves, no limit being placed upon their choice; (2) To limit the choice to the staff of the hospital, the members of which shall agree to accept a fixed scale of payment. The latter plan is the only one which offers any prospect of solving the difficulty about expense, and will therefore probably be tried. The points upon which the medical profession should be united are: (I) The undesirability of any members of the staff undertaking to give their services to paying patients in return for a fixed annual salary; and (2) That no member of the staff shall be required against his will to undertake work in the pay wards as part of his duty to the hospital. The schedule of fees to be charged in the pay wards must be subject to arrangement between the hospital managers and the medical staff in each case, as it is clear that the fees must vary in different places and with the training and special skill of the staff. 


\section{Payment of a Substitute.}

It is usual to offer half fees to a substitute who has seen patients during a practitioner's absence from illness or otherwise, but where there is a reasonable prospect of such services being reciprocated, payment is often declined.

\section{Practice OF Midwifery By Students.}

Students of medicine are compelled by the regulations of the General Medical Council to attend a certain number of cases of labour, and there is nothing illegal in their attending more than that prescribed number; but it is not desirable that they should attend cases for payment except in the capacity of pupil-assistant to a duly qualified medical practitioner.

\section{PRESCRIPTIONS.}

A patient who has paid for a consultation has a right to the prescription, and this must not be withheld from him by his medical attendant, to whom it may have been sent, if he desires to have it. On the other hand, no patient has the right to insist upon having a prescription given to him for medicine which has hitherto been supplied by his medical attendant.

There is no law in England to prevent a prescription being dispensed over and over again, nor is there anything to prevent a pat:ent parting 
with a prescription, or giving copies of it to others, but such a proceeding is obviously unfair towards the original prescriber. The handing on of prescriptions is a practice not unattended by risk of injury to those persons who swallow medicines ordered for others.

It is doubtful whether the sale of medicine made up according to a prescription originally obtained by payment of a fee could be prevented, but it is probable that the law would not allow the prescriber's name to be used.

\section{Professional Secresy.}

Although there is no statutory duty imposed upon medical practitioners in this country to maintain the rule of professional secresy, the obligation of the Hippocratic oath is nevertheless binding: "Whatever, in connection with my professional practice, or not in connection with it, I see or hear, in the life of men, which ought not to be spoken abroad, I will not divulge, as reckoning that all such should be kept secret." It is hardly necessary to insist upon the need for the careful avoidance of aught that savours of gossip respecting the cases under our care.

A medical man is not allowed to refuse to testify in a court of law to facts which have come to his knowledge in the course of his professional duties. 
While members of the medical profession must obey the law, and aid the course of justice, they are not called upon to act the part of detectives or informers.

It may be asked, what should be the duty of a medical man who in the course of his professional work learns that a grave crime has been committed, or is about to be committed? The answer is, that his action must depend upon the certainty of his knowledge. He must not mistake inferences for facts, and if this distinction is borne in mind a medical practitioner will have no difficulty in coming to a right conclusion, unless he is disposed to become particeps criminis.

In general, let the medical practitioner observe the rule that he has no right to reveal to any person information acquired by medical examination, without the consent of the patient. Wherever he may fear that his silence may prejudicially affect an innocent third person, he should point out to the patient the means to be adopted in order to prevent these consequences, and if the patient refuses his assistance, the medical practitioner may be compelled to take the necessary steps himself.

The law, by compelling the notification of infectious diseases, obliges us to violate professional secresy, and in certain cases of non-notifiable infectious diseases, the dangers run by 
innocent persons may compel us to disclose our patient's secrets ; but it ought not to be necessary to do this, as it should suffice to give such warnings as may prevent danger. Even this should only be done when the patient has refused to act properly.

In examining a servant for an employer, care should be taken, before any examination is made, to see that the patient understands that the examination is being made on behalf of the employer, and that the information derived will be made known to the employer. No medical practitioner is justified in making an examination of any person at the sole instance of an employer, or the police, coroner, or similar authorities. Such an examination without the free consent of the person concerned, would be technically an assault, and would expose the medical practitioner to an action for damages.

Where a child is examined at the request of a parent, there can be no violation of professional secresy in telling the parent the result of the examination. Parents and relations have no right to obtain from a doctor the result of his examination, although in a great many cases it is quite proper to tell them.

Our attitude, therefore, on the question of professional secresy is somewhat elastic, and perhaps illogical. While we should never be 
willing to give information which may be used to the prejudice of a patient, we should not stickle for professional secresy when it is clearly to the disadvantage of the patient that information should be withheld. To decide this question does not call for a greater exercise of judgment than must be shown in many other problems met with in the daily practice of the medical profession.

\section{PROGNOSIS.}

So far as our knowledge permits, our prognosis should be truthful, and should so far as may be reflect our thoughts; but it is permissible to diminish the gravity of our view of his case to a patient who is very seriously ill, and to speak with perfect hopefulness in order to encourage a patient who may be suffering from a troublesome, though not a dangerous affection.

As a rule there is little difficulty in saying as much as we please, for patients do not often press us with questions; but where a patient insists upon knowing the truth he should be told.

In all cases of serious illness the patient's family should be told the plain truth.

\section{READING AND STUdy.}

It is the duty of every medical practitioner, while in practice, to keep up his knowledge by 
reading and study, so far as his time will allow. This he may very well do by reading a weekly medical paper, and by buying from time to time good works of reference, which should be consulted when unfamiliar cases come under his notice.

\section{Resigning Cases.}

A medical practitioner is justified under certain conditions in refusing to continue attendance on a case ; where, for example, he finds another practitioner is in attendance, or where other than remedies prescribed by him are being used, or where his remedies are refused, or where he is convinced the illness is an imposture and he is being made a party to a false pretence.

$\mathrm{He}$ is not in any way bound to give up a case because it is incurable, so long as the patient desires his services.

He may, however, justifiably refuse to continue in attendance where the patient persists in the abuse of alcohol, opium, chloral, or similar poisons; but it would generally be better to continue in attendance, and endeavour with the aid of the patient's friends to check the dangerous habit.

\section{Secret Remedies.}

Medical practitioners should not use secret remedies. They are not, however, obliged to 
give patients the exact details of the treatment employed; if the patient asks for them it is better to satisfy him, or he may take offence and seek another medical adviser.

Nostrums are special preparations of which the formulæ are wholly or partially unknown. As a general rule such preparations should not be ordered, as it is unscientific to make use of remedies of whose nature we are ignorant; but in many cases we know substantially all that is necessary, and where this is the case their use may be justified. Simplicity in prescribing is much to be desired for the advancement of therapeutics, and this is a reason for declining to employ the complicated compounds of the wholesale druggist. but it does not amount to an ethical objection to their use.

\section{Trade Testimonials and Puffs.}

Medical practitioners should not give trade testimonials to be used for advertising, and they should be very careful about mentioning specialties in their published writings. No doubt there are specialties which have earned for themselves a very high place in the esteem of the medical profession, and there is sometimes so much difference between the article supplied by different makers, that it is necessary to specify the maker's name in order to be sure of a satisfactory result ; 
but an insidious form of puff has arisen of late years, which takes the form of an article upon the treatment of disease, that when looked into, is seen to be written solely for the purpose of extolling the virtues of a nostrum. Such articles are not easily imposed upon judicious editors, but they find their way into the less important medical journals, and are then reprinted and circulated, or quoted in advertisements.

Caution must be exercised in writing letters, or even giving oral expression to opinions which may be used for advertising purposes; a recent decision shows that the Courts of Law will afford little protection to medical practitioners against the unauthorised use of their names.

A circular was issued by a member of the medical profession asking for advertisements to be inserted in a publication of his, and offering for a certain payment that "a testimonial will as usual be appended to each advertisement, and the author will make a point of frequently alluding to these in print, and in many other ways. If desired, he will send an excellent brief recommendatory letter on your specialty." A letter was sent by a firm of chemists to a medical practitioner asking him to examine a sample of a drug, and to write an 
article in its favour, for which they offered him payment. The drug in question was not new, or one which there was any difficulty in obtaining pure, so that there was no justification for asking for any special recommendation. These cases prove that there is ground for drawing attention to this subject. No one can doubt that such means of making money are illegitimate

\section{UNDERSELLING.}

While it is impracticable to fix the rate of payment for medical services, as this must vary according to circumstances, yet medical men should in each district agree to a common minimum, and must not seek to gain advantage over one another by underselling.

Those who do so must not complain if they find they have placed themselves outside the circle of neighbour'y courtesy and goodwill.

\section{Vaccination and Public Vaccinators.}

Public vaccinators should not call upon the patients of other medical practitioners without notice, nor should they issue circulars offering free vaccination. If, in the face of an epidemic, it is thought necessary to issue such notices, this should be done by the local authority, and they should be signed, if at all, by the clerk to the authority. 


\section{Visits to Patients.}

Medical practitioners must be allowed to visit patients as often as they think necessary, but they should be careful not to multiply unduly these visits, or to continue them longer than the case requires.

It is very undesirable to pay friendly visits to a patient who is under the care of another medical man. It is quite possible that such visits may be made in perfect good faith, but they frequently lead to unpleasantness, and had much better be avoided.

Vivisection. (See Experiments on Animals).

Witnesses in COURTS OF LAW.

Medical practitioners are constantly called upon to give evidence in courts of law, both criminal and civil, and their testimony is often of the highest possible importance.

The appearance made by medical men in the law courts has a good deal to do with the general estimation in which they are held, and it is therefore of moment to their profession that they should conduct themselves so as to earn the respect of those who listen to them.

It may be premised that, as a rule, the medical witness is the only person in court with the exception of other medical witnesses who may be 
present) who thoroughly knows the subject about which he is talking; but it must not be forgotten that successful barristers are men whose training enables them to pick up very quickly a certain amount of knowledge on any subject, and it will not do to rely upon their ignorance. If the medical witness really understands his case, he need not be afraid of any barrister; he should, before going into the witness box, clarify his idleas as much as possible, and make up his mind what are the essential things he wishes to lay before the court, and he should seek the least technical language in which io express them. With respect to his matter, let him imagine that he is going to address a medical society, and say nothing which he would not feel sure would meet with the approval of his medical brethren : if in doubt about any pathological or toxicological point he should admit the doubt. A medical witness should be very little of a partisan. He should give his candid opinion of the case, and if, upon that, the lawyers are willing to call him, he can have no objection to going into the witness box; but he must absolutely refuse to have his opinions suggested to him. His conclusions should be moderately stated; he should give due weight to any facts which tell against his client. By adopting this attitude he will be, not a less, but a more 
effective witness for the side on which he is employed, for the jury is more likely to be guided by a medical witness who is evidently fair and moderate in his statements, than by one who shows bias.

If a medical practitioner, after being consulted as an expert by one side, is informed that he will not be called, it may happen that he may be approached by the other parties with a request to give evidence for them; it is right that he should refuse, as he could not well avoid making use of information which he had acquired when he stood in a trusted position towards the other side. This rule, however, applies only to experts, and not at all to witnesses to facts, who of course cannot refuse to testify to those facts, whichever side calls them. 
APPENDIX.

Extracts from the Bye-laws and Regulations of the General Medical Council and Medical Corporations, relating to the conduct of members of the medical profession.

Regulations of the General Medical Council.

I.-AS to the EMPLOYMENT OF UNQUALIFIED Persons as Assistants or Otherwise, DiRECTED TO BE ISSUED BY RESOLUTION ADOPTED BY THE General Council on November 24, i 897.

WHEREAS it has from time to time been made to appear to the General Medical Council, that some registered medical practitioners have been in the habit of employing, as assistants in connection with their professional practice, persons who are not duly qualified or registered under the Medical Acts, and have knowingly allowed such unqualified persons to attend or treat patients in respect of matters requiring professional discretion or skill: and whereas in the opinion of the Council such a substitution of the services of an unqualified person for those of a registered medical practitioner is in its nature fraudulent and dangerous to the public health : The Council 
hereby gives notice that any registered medica! practitioner, who is proved to have so employed an unqualified assistant, is liable to be judged as guilty of "infamous conduct in a professional respect," and to have his name erased from the .Medical Register under the 29th Section of the Medical Act, i 858 .

Further, in regard to the practice commonly known as "covering," the Council gives notice that any registered medical practitioner, who by his presence, countenance, advice, assistance, or co-operation, knowingly enables an unqualified or unregistered person (whether described as an assistant or otherwise) to attend or treat any patient, to procure or issue any medical certificate or certificate of death, or otherwise to engage in medical practice as if the said person were duly qualified and registered, is liable to be judged as guilty of "infamous conduct in a professional respect," and to have his name erased from the Iledical Register, under the said enactment.

But the foregoing notices do not apply so as to restrict the proper training and instruction of bona-fide medical students as pupils, or the legitimate employment of dressers, midivives, dispensers, and surgery attendants, under the immediate personai supervision of registered medical practitioners.

\section{II.-AS to Association with UnREgistered DENTISTS.}

Resolution passed by the General Council on December Ist, i 898 :- 
"Any registcred medical practitioner who knowingly and wilfully assists a person who is not registered as a Dentist in performing any operation in dental surgery, either by administering anæsthetics or otherwise, will be liable, on proof of the facts, to be dealt with by the General Medical Council as having been guilty of infamous conduct in a professional respect."

\section{III.-As to Association with Medical Aid Societies.}

Resolution passed by the General Council on June 6th, I 899 :-

"That the Council strongly disapproves of medical practitioners associating themselves with medical aid associations which systematically practise canvassing and advertising for the purpose of procuring patients."

IV.-As to the Illegal Sale to the Public in Medical Halls or Open Shops of Scheduled Poisons, or Preparations containing ScheDULED POISONS.

Notice issued by the General Council on December 2nd, I90 I :-

"Whereas it has been made to appear to the General Medical Council that certain registered medical practitioners, who keep medical halls or open shops in which scheduled poisons or preparations containing scheduled poisons are sold to the public, have been accustomed to leave 
in charge of such halls or shops assistants who are not legally qualified to sell scheduled poisons to the public; and that such practitioners have thereby, for their own profit, and under cover of their medical qualifications, enabled such unqualified assistants to sell scheduled poisons, and so to commit breaches of the law; and whereas, in the opinion of the Council, such practices on the part of a registered medical practitioner are professionally discreditable and fraught with danger to the public, the Council hereby gives notice that any registered medical practitioner who is proved to have so offended, is liable to be judged as guilty of 'infamous conduct in a professional respect,' and to have his name erased from the Medical Register under the 29 th Section of the Medical Act, I 858 ."

Extracts from the Bye-laws and Regulations of the Royal College of Physicians of London.

No Fellow of the College shall be entitled to sue for professional aid rendered by him. (Byelaw I 70.$)$

If two or more Physicians, Fellows or Members of the College, be called in consultation, they shall confer together with the utmost forbearance, and no one of them shall prescribe, or even suggest, in the presence of the patient, or the patient's attendants, any opinion as to what ought to be done, before the method of treatment has been determined by the consultation of him- 
self and his colleagues; and the physician first called to the patient shall, unless he decline doing so, write the prescription for the medicines agreed upon, and shall sign the initials of the physicians or physicians called in consultation, he placing his own initials the last. If any difference of opinion should arise, the greatest moderation and forbearance shall be observed, and the fact of such difference of opinion shall be communicated to the patient or the attendants by the physician who was first in attendance, in order that it may distress the patient and the friends as little as possible. (Bye-law i 74.)

No Fellow, Member, or Licentiate of the College shall officiously, or under colour of a benevolent purpose, offer medical aid to, or prescribe for, any patient whom he knows to be under the care of another legally qualified medical practitioner. (Bye-law I 75.)

No Fellow or Member of the College shall be engaged in trade, or dispense medicines, or make any engagement with a chemist or any other person for the supply of medicines; or practise medicine or surgery in partnership, by deed or otherwise; or be party to the transfer of patients, or of the goodwill of a practice, to or from himself, for a pecuniary consideration. (Bye-law i 76

No Fellow, Member, Extra Licentiate, or Licentiate of the College shall assume the title of Doctor, or. append to his name the title of Doctor of Medicine, or the letters M.D., or any other letters indicating that he is a graduate of 
a university, unless he has obtained a degree entitling him to do so. (Bye-law 177.)

No Fellow, Member, or Licentiate of the College shall refuse to make known, when so required by the president and censors, the nature and composition of any remedy he uses (Byelaw I 78 .)

Licentiates of this College shall not compound or dispense medicines, except for patients under their own care. (Bye-law I 80.)

Certain resolutions relating to professional conduct have been adopted at various times by the College, as follows :-

On the 9th day of June, I873, the College passed the following resolutions:-

"That the practice of medical authors frequently advertising their own works in the non-medical journals, and especially with the addition of laudatory extracts from reviews, is not only derogatory to the authors themselves, but is also injurious to the higher interests of the profession."

On the 27th day of December, I88I, the College passed the following resolution :-

"That while the College has no desire to fetter the opinion of its members in reference to any theories they may see fit to adopt in connection with the practice of medicine, it nevertheless considers it desirable to express its opinion that the assumption or acceptance by members of the profession of designations implying the adoption of special modes of treatment, is opposed to those 
principles of the freedom and dignity of the profession which should govern the relations of its members to each other and to the public.

"The College therefore expects that all its Fellows, Members, and Licentiates will uphold these principles by discountenancing those who trade upon such designations."

On the 27th day of July, I882, the College passed the following resolution :-

"That the system of extensively advertising medical works, and the custom of giving, whether for publication or not, laudatory certificates of medic:nal and other preparations, or of medical or surgical appliances, is misleading to the public, derogatory to the dignity of the profession, and contrary to the traditions and resolutions of the Royal College of Physicians."

On the 2nd February, I 888, the College passed the following resolution :-

"That it is undesirable that any Fellow, Member, or Licentiate of the College should contribute articles on professional subjects to journals professing to supply medical knowledge to the general public, or should in any way advertise himself, or permit himself to be advertised in such journals."

On the $25^{\text {th }}$ of October, 1888, the College passed the following resolution :-

"That it is undesirable that any Fellow or Member of the College should be officially connected with any company having for its object the treatment of disease for profit " 
Extracts from the Bye-lazes and Regulations of the Royai College of Physicians of Edinburgh. Chapter vii. Section I.

No Fellow or Member of the College shall by himself, co-partners or servants, keep a public apothecary's, druggists', or chemist's shop. If any Fellow or Member of the College shall by himself, co-partners, or servants, keep a public apothecary's, druggist's, or chemist's shop, he shall, ipso facto, forfeit all the rights and privileges which he does or may enjoy as a Fellow or Member of the College, and his name shall be expunged from the College list.

Extracts from the Bye-laws and Regulations of the Royal College of Surgeons of Edinburgh.

Chapter iv. Sections 13, I4, I5, 16.

(13) No Fellow of the College shall keep an open shop for the sale of drugs or other merchandise.

(14) No Fellow of the College shall allow his name to be connected with advertisements or publications of an indelicate or immoral nature.

15) No Fellow of the College shall practise, or profess to practise, by the use of or according to any secret remedy or method of treatment; or shall allow his name to be connected with advertisements for the sale of any secret remedy, or practise by the use of any secret remedy or method of treatment; or shall connect himself in partnership or otherwise, or continue in connec- 
tion, with any person practising by means of or advertising the sale of any secret remedy.

(I6) No Fellow shall be guilty of any deception or other immorality in the practice of his profession, or shall in any other way conduct himself inconsistently with the honour and decorum which become his position as a Fellow of the College.

Extract from the Regulations of the Faculty of Physicians and Surgeons of Glasgow.

No Fellow of the Faculty shall keep an open shop for the sale of drugs or other merchandise, or be a proprietor or have any proprietory interest in a secret remedy.-Chapter vii. Page I4. Section I.

Extracts from the Bye-lazes of the Royal College of Physicians of Ireland.

Every candidate, before being enrolled a Member of the College, shall subscribe the following declaration in the presence of the President and Fellows :-

"I hereby authorise the President and Fellows of the Royal College of Physicians of Ireland to erase my name from the list of members, and I consent to surrender the diploma received from the College, if I shall, after having obtained the Membership, engage in trade, or if I shall dispense medicine, or make any engagement with a chemist or other person for the supply of medicine, or if I shall practise medicine or surgery in part- 
nership, by deed or otherwise."-Chapter iii. Section 24.

Every candidate, before being admitted as a Licentiate of the College, shall subscribe the following declaration, viz. :-

"I engage not to endeavour to obtain practice, or to attract public notice, by any unworthy means; I also engage that I will neither permit nor sanction the use of my name by any other person for such purposes, nor in connection with any secret remedy; and in case of any doubt relative to the true meaning or application of this engagement, I promise to submit to the judgment of the College.-Chapter iv. Section 3I.

(93) “Any Fellow, Nember, or Licentiate of this College who, in the judgment of the College, shall be deemed guilty of conduct unbecoming the profession of physic, shall be placed under the censure of the College."-Chap. xi. Sec. 93.

(94) "No Fellow, Nember, or Licentiate of this College shall consult with any Fellow, Nember, or Licentiate who is under censure."Chap. xi. Sec. 94.

(95) "No Fellow, Nember, or Licentiate of this College shall consult with any person who shall have been pronounced guilty of any conduct unbecoming the profession of physic."-Chap. xi. Sec. 95 .

RESOLUTIONS.

"That the revicwing or advertising of medical works in other than medical publications, and 
the giving by any of the Licentiates, Members, or Fellows of this College, whether for publication or not, laudatory certificates of medicinal or other preparations, or of medical or surgical appliances, is misleading to the public, derogatory to the dignity of the profession, and is open to censure by the Royal College of Physicians of Ireland."-Resolution Io.

"That the Royal College of Physicians of Ireland desire to express their disapproval of their Licentiates accepting office in medical aid associations as at present conducted in England, inasmuch as the independence of the physician is destroyed by the system, and the services of the physician are used so as to produce a profit for lay persons."-Resolution of November $3 r d$, I 893 .

"That the Royal College of Physicians of Ireland condemn the employment of unqualified assistants by any of their Licentiates, and instruct their representative on the General Medical Council to urge the Council to suppress the practice by every means in their power."-Resolution of January 8th, I 897 .

"That in the opinion of the President and Fellows, a Fellow, Member, or Licentiate, may by courtesy and usage call himself "doctor," but he has no right to use the letters "M.D.," or call himself "Doctor of Medicine," unless he holds that degree from a university."-Resolution of April 6th, I90I. 
Extracts from the Bye-lawes and Regulations of the Royal College of Surgeons of Ireland.

"Any Fellow who shall be convicted before the Council of having made a false or corrupt report, or gives a false certificate to any magistrate, insurance company, public board, or other body or individual, respecting the state of health of any person, shall be expelled; and if a Licentiate shall be so convicted, his letters testimonial shall be withdrawn.-(Bye-law II.)

\section{Obligations of Licentiates.}

"No Fellow or Licentiate of the College shall seek for business through the medium of advertisement, or by any other disreputable method, or shall consult with, advise, direct, assist, or have any professional communication with any person who professes to cure clisease by the deception called Homoepathy, or by the practice called Mesmerism, or by any other form of quackery, or who follows any system or practice considered derogatory or dishonourable by physicians and surgeons. And be it furthermore resolved, that, in the opinion of the Council, it is inconsistent with professional propriety and derogatory to the reputation, honour, and dignity of the College, to engage in the practice of Homoeopathy or Mesmerism, or any other form of quackery as hereinbefore set forth." 


\section{IN DEX.}

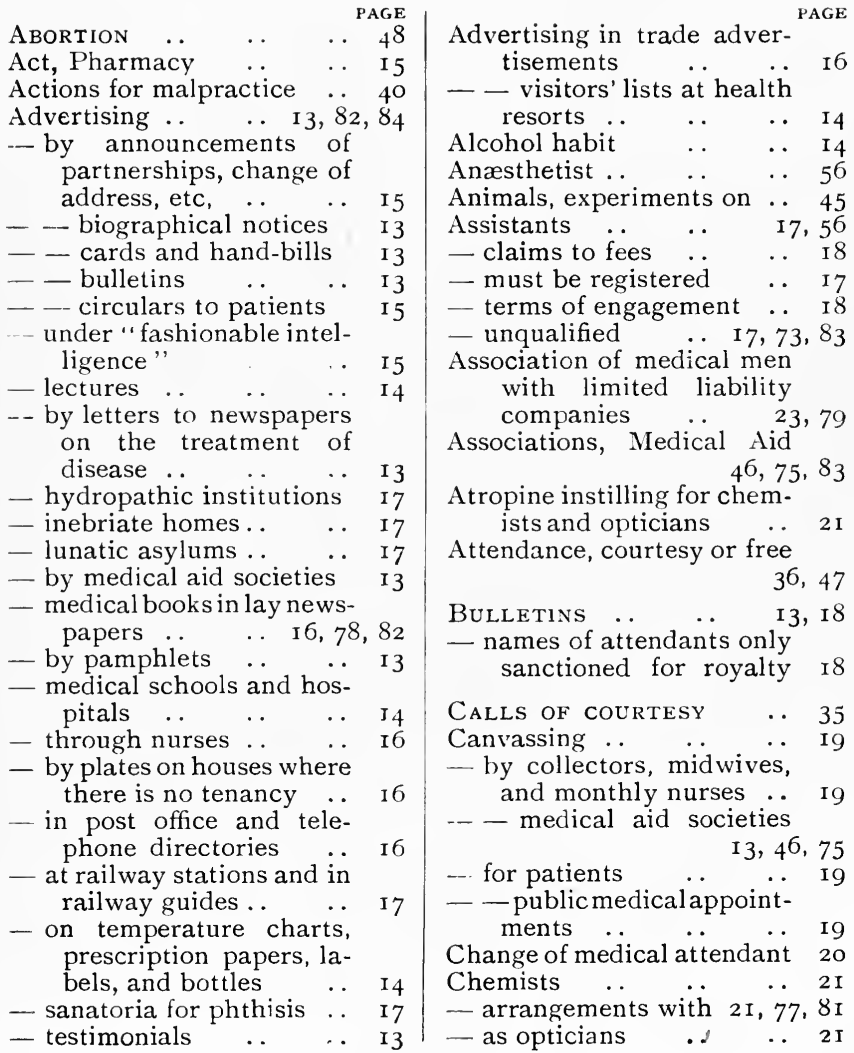


Chemists, commission on ${ }^{\text {PAGE }}$ medicines

- consultations with .. 2 I

- covering .. ...

- instilling atropine .. 2 I

$\begin{array}{llll}\text { Commission .. } & \text {. } & \text {. } & 22\end{array}$

- from chemists .. $\quad . .2$ I

- by fee sharing . . $\quad$. 22

- from insurance companies 23

- - proprietors of lunatic asylums to relieving $\begin{array}{llll}\text { officers .. } & \text {. } & . & 22\end{array}$

- - tradespeople or dentists 22

- to hotel proprietors, lodging-house keepers, monthly nurses, and midwices

Companies, association with limited liability

Consultants, duty of

_ _ _ where consulted independently of medical attendant

.. . .

_... - where medical at. tendant becomes unacceptable

. 29

- interference by .. 27,77

- not to take sole charge of $\begin{array}{lllll}\text { case } & \text {. } & \ldots & \ldots & 27\end{array}$

- selection of $\quad \ldots \quad$. 24

Consultations $\quad$. $\quad$. . 24

- between general practi. $\begin{array}{lllll}\text { tioners } & . & \ldots & \ldots & 27\end{array}$

- by letter .. $\quad$. $\quad$.. 30

- duty of suggesting .. 24

- failure to keep appointment .. $\quad$. $\quad$. 25

$\begin{array}{llll}- \text { to agree } & \ldots & \ldots & 25\end{array}$

$\begin{array}{llll}\text { - fixing time of } & . & \ldots & 25\end{array}$

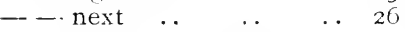

-- in British colonies and foreign countries .. 30

- in consulting rooms .. 27

$\begin{array}{llll}\text { - procedure of } \quad . . & \text {. } & 25\end{array}$

- refusal to meet consultant 24

-... stating conclusions .. 26

-. statements by patients .. 28

- statement of case by medical attendant $\quad . \quad 28$
Consultations to be held with all duly qualified practitioners

- when treatment should be carried out by con. sultant, and when by medical attendant .. 29

- with foreign physicians 30

- with homoeopaths 3I, 78, 84

- with midwives .. $\quad . .30$

Contracts not to practise .. 33

Coroners' inquests .. $\quad$. $\quad 34$

$\begin{array}{llll}\text { C - evidence at } & . & \ldots & 35\end{array}$

- - post mortem examinations .. $\quad$. 3 .. 34

$\begin{array}{llll}\text { Courtesy calls } & \ldots & \ldots & 35\end{array}$

— title of Dr. . . . . 36

- attendance on dentists .. 38

_. _ _ doctors and their $\begin{array}{llll}\text { families .. } & \ldots & \ldots & 36\end{array}$

_ - - medical students.. 37

- nurses $\quad . \quad$ - . 37

Courts of law, evidence in

Covering $35,62,70$

Defence Associations .. 40

Dentists .. . . . 38

- association with unregis. tered $\ldots \quad \ldots \quad 38,74$

- courtesy services to and from $\quad \ldots \quad$. $\quad \ldots \quad 38$

Disease, notification of $\quad \ldots 63$

Dispensaries.. $\quad \ldots \quad \ldots \quad 38$

Dispensers, unqualified 17,75

Dispensing $\quad \ldots \quad \ldots \quad 78,8$ r

Doctor, title of $\quad \cdots \quad 36,77,83$

- $\begin{array}{llll} & \text { and patient } \quad . . & . & 39\end{array}$

_... gifts from patients 40 - - medical defence .. $4 \mathrm{I}$

Doctors' shops $\quad 41,75,80,8 \mathrm{r}$

Drug habits .. $\quad . . \quad \ldots 4$ II

Duty of medical practitioner to workman consulting him $\quad \ldots \quad \ldots \quad \ldots 43$

Eningurgh, REgUlations of R.Cs. P. and S. of 80

Emergency calls $\quad \ldots \quad \ldots \quad 42$ 
INDEX.

Emergency calls, right to a

$\begin{array}{lllll}\text { case } & \ldots & \ldots & \ldots & 43\end{array}$

Employers' liability $\quad$. 43

- - fees for certificates .. 45

- medical practitioner's

duty defined .. $\quad$. 44

Evidencein courtsof law $35,62,70$

- no professional privilege

$$
\text { in } \quad . . \quad \ldots \quad \ldots 62
$$

Examinations foremployers 43,64

- - insurance companies 50, 54

- - parent.. $\quad . . \quad \ldots 64$

- - police or coroner .. 64

- - railway companies .. 54

Experiments on animals .. 45

- - patients . 45,55

Extracts from bye-laws and regulations of General

Medical Council .. 73

_ _ - R.C.P. London .. 76

- - R.C.P. Edinburgh 80

_ - _ R.C.S. , . . 8o

- - - F.P. and S. Glasgow 8I

- - R.C.P. Ireland .. 8 8

- - R.C.S. ,

FEes FOR CERTIFICATES . . 45

- from hospital patients $46,5^{8}$

- underselling in .. .. 69

Friendly societies .. 46,75

General Medical Council, regulations of .. $\quad \ldots \quad 73$

Gifts from patients .. . . 40

Glasgow, regulations of the F.P. and S. .. $\quad . \quad 8 \mathrm{r}$

Gratis medical attendance 47

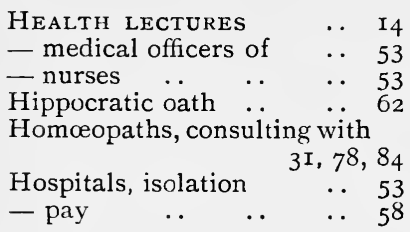

I.NCURABLE DISEASE, DRUGS

in

.. 42
Induction of premature

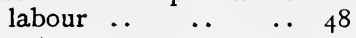

$\begin{array}{lllll}\text { Inquests } & \ldots & \ldots & \ldots & 34\end{array}$

Inspectors, sanitary $\quad . .53$

Instruction in midwifery $49,6 \mathrm{I}$

Insurance companies $\quad \ldots \quad 50$

Ireland, regulations of the R.C.P. .. $\quad . . \quad \ldots 8 \mathrm{I}$

- - - of the R.C.S. $\quad \ldots \quad 84$

Isolation hospitals .. $\quad$. 53

LABOUR, INDUCTION OF PREmature .. $\quad$. $\quad$. 48

Lectures, advertising $\quad . . \quad 14$

Limited liability companies, $\begin{array}{ll}\text { connection with } & 23,79\end{array}$

Locum tenens $\quad \ldots \quad \ldots 50$

- - duties of $\quad . \quad . \quad . \quad 50$

- - no right to fees $\quad . \quad 50$

- - not to start practising in neighbourhood $\quad \cdots \quad 50$

- - rights of $\quad$. $\quad \ldots \quad 50$

London, regulations of R.C.P. of $\quad$. $\quad \ldots 76$

Lunacy certificates.. $\quad$.. 40

Lunatic asylums .. $\quad 17,22$

MALPRACTICE, ACTIONS FOR 40

Marriage $\quad \ldots \quad \ldots \quad \ldots 5$ I

— and mental disease $\quad . \quad 52$

- - organic disease .. 52

- - transmissible disease 52

Medical aid associations

$46,75,83$

- attendant, change of ... 20

- defence associations .. $4 \mathrm{I}$

- expert witnesses $\quad$. 72

- officers of accident insurance companies $\quad$.. 54

- - - health $\quad . . \quad$.. 53

- referees in railway cases 54

- - not to be detectives .. 54

- witnesses .. $\quad . . \quad \ldots \quad 70$

Midwifery, instruction in $49,6 \mathrm{I}$

- practice of, by students 6r

Midwives, co-operation with

I $\bar{i}, 22,30$

— canvassing by $\quad . . \quad$.. 


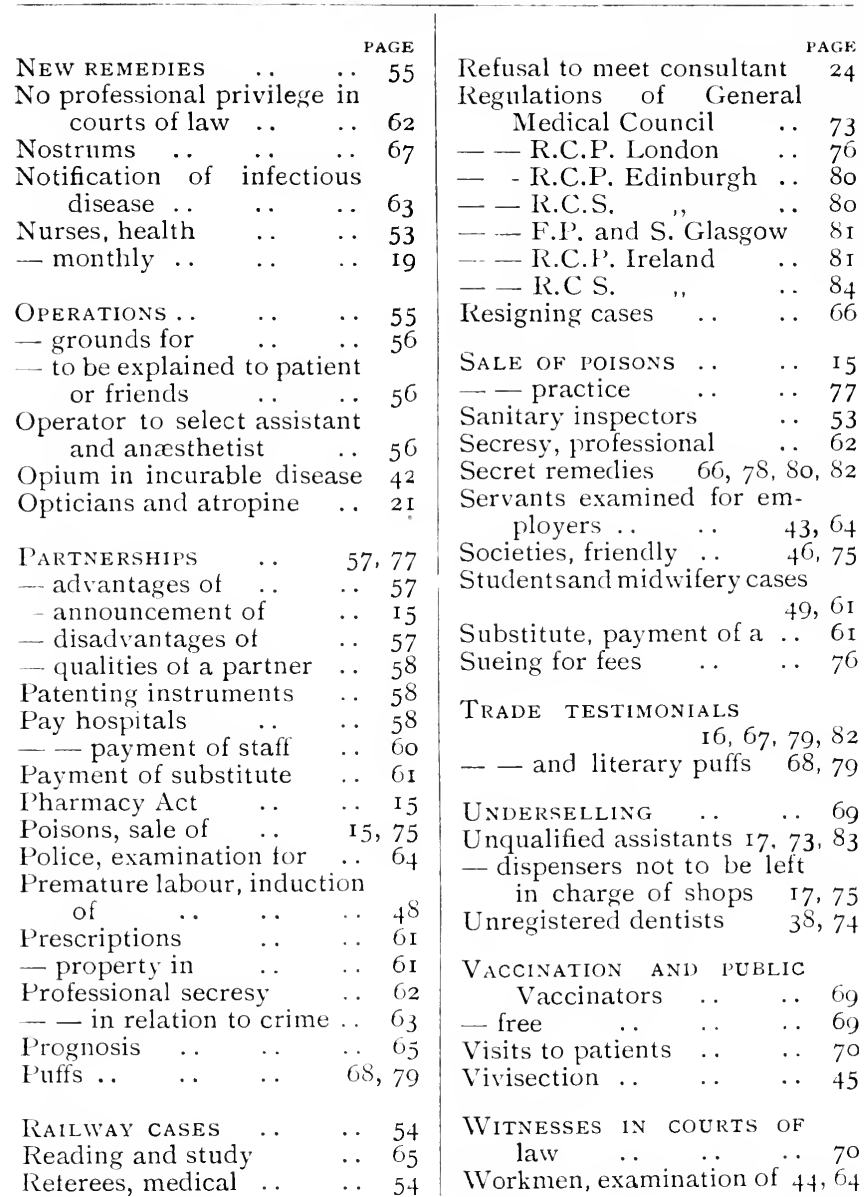


JOHN WRIGHT \& CO., Medical Publishers and Printers, Bristol, are always prepared to negociate for the Publication of Medical and Scientific Works upon the best terms, and avith the greatest excellence of workmanship.

Full Catalogues free on application.

BY THE SAME AUTHOR.

Fourth Edition. Revised. Large 8vo. Cloth. $450 \mathrm{ff}$. Io/6 net.

With 67 Illustrations and Four Coloured Plates.

\section{LECTURES ON RENAL AND URINARY DIS-}

EASES. By Robt. Saundby, M.D. Ed., F.R.C.P. Lond., LI.D. Emer. Senr. Pres. of Royal Med. Soc.; Fellow Royal Medico-Chirurgical Soc. ; Member Path. Soc. of London; Phys. General Hospital ; Cons. Phys. to the Eye Hosp. ; Cons. Phys. Hosp. for Dis. of Women; Prof. of Medicine in Mason Coll., Birmingham; Late Exam. in Med. to the Examining Board for England.

"The volume makes a favourable impression at once; it is well printed and sufficiently illustrated : it contains a good index both of proper names and of subjects. Appended to each chapter is a sufficient list of references; and the text of each concludes with a summary of its argument, in one instance with a summary also of the gaps in our knowledge-an admirable device for pricking balloons. The style of the work is clear and sitccinct. We cannot find any part of the subject upon which the views expressed are not carefully thought out, and fortified by evidence drawn from the most recent sources. The book may be cordially recommended as one which may be read with great interest and profit."Brit. Med. Journ.

"A work which embraces questions of great pathological moment that have for long received much attention in the scientific world; it is the production of one who has devoted especial care to the study of these subjects."-Lancet.

"The publication of these lectures in one volume. and marked by such revision and addition as the progress of the last few years has required, is in itself a matter of congratulation."-New York Med Journ.

Twentieth Year. 8vo. About 900 pages. $7 / 6$ net.

With many Finely Coloured and other Flates, and Numerous Illustrations.

THE MEDICAL ANNUAL: A Year-Book of Treatment and Practitioner's Index. Comprising a Dictionary of Nateria Medica and Therapeutics, A Dictionary of Medicine and Surgery, Various Special Articles, and much General Information.

Similar in size to the "Medical Annual." $7 / 6$ net.

THE MEDICAL ANNUAL SYNOPTICAL INDEX TO DRUGS AND TREATMENT, FOR THE TwELVE YeARS I 887 TO 1898 . 
JOHN IVRIGHT $\underset{0}{ }$ CO., Publishers and Printers, BRISTOL.

Fourth Edition. Revised, and Greatly Enriched and Enlarged. Comflete with 93 Coloured and Steveoscopic Illustrations, and 222 Black and White Drawings, including Steveoscope. I7/6 net.

DISEASES OF THE UPPER RESPIRATORY TRACT: The Nose, Pharynx and Larynx, including the examination of the Ear. By. P. Watson Willialis, M.D. Lond., etc.

680 th. Illustrated by over 500 Original Drawings by the Author, and Numerous Woolicuts. ro/6 net.

OPERATIVE AND PRACTICAL SURGERY: For the use of Students and Practitioners. By Thomas Carwardine, M.S. (Lond.), F.R.C.S.

Fourth Edition. Revised and partly Re-written, with Additional Chaters, and 26+ Illustritions on ITood. Io/6.

PYE'S SURGICAL IINDICRAFT: A Manual of Surgical Manipulations, Minor Surgery, etc. For the use of Students and Practitioners. With Special Chapters on AURAL SURGERY AN1 THE TREATMENT OF TEETH, by Messrs. FiELD and Sidney Spokes. Revised and Edited by Bertram M. H. Rogers, B.A., M.D., B.Ch. Oxon.

Second Eidition. Serenth thousunt. Tery complete. 200 Orighal Drawings. Simall $800.2 / 6$.

"FIRST AID" TO THE INJURED AND SICK: An Adranced Ambulance Handbook. By F. J. Warwick, B.A., II B. (Cantab.), II.R.C.S., L.S.A.; and A. C. TUNSTAI.I, M.D., F.R.C.S. (Edin.).

LANTERN SLIDES FOR LECTURING.-Plain I/- each; Coloured from $2 /$ - each.

On Sheots $3 f l .+$ ins. by 2 ft. 2 ins. $2 /-$ itch, or $27 / 6$ the Sit of 16 with Nickeld Heal for Susfension. DDOpted BY THE IVAR OfFice.

"FIRST-AID"IARGE SHEET DIAGRAMS. Being Enlargements of the illustrations in the above book, suitable for Lectures and Classes.

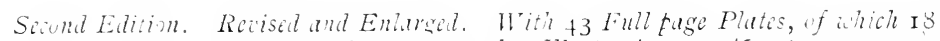
we in colours, and numerous other Illustrations. $9 / 6$ net.
AN INTRODLCTION TO DERMATOLOGY' By Normax Walker, M.D. 
JOHN WRIGHT \& CO., Publishers and Printers, BRISTOL.

Large 8vo. $574 \mathrm{pp}$. Strongly bound. 12/6 net.

A TEXT-BOOK OF HISTOLOGY: Descriptive and Practical. For the use of Students. With 174 beautifully coloured original plates, and other illustrations. By Arthur Clarkson, M.B., C.M. Edin.

Large 8vo. 492 pp. IVith I2 Full-page Illustrations. Io/6 net.

THE SURGERY' OF THE CHEST: For Students and Practitioners. By Stephen Paget, M.A. Oxon, F.R.C.S.

Second Edition. 8vo, Cloth. Illustrated. 4/- net.

URINARY SURGERY: An Epitome of Modern Surgical Progress. By E. Hurry Fenwick, F.R.C.S.

Ninth Edition. Pocket size. So Illustrations. Cloth, $2 \%$

Adopted by the St. John Ambulance Association.

PYE'S ELEMENTARY BANDAGING AND SURGICAL DRESSING : With Directions for Treatment of Cases of Emergency. Mostly condensed from "Pye's Surgical Handicraft." Ninth Edition, Revised and in part Re-written by THOS. CARIAARDINE, M.S., F.R.C.S.

Crown 8vo. Cloth. 3/-net.

SURGICAL TECHNICS: A Handbook for House Surgeons, Students, Dressers and others engaged in Hospital Work By K. IV. Monsarrat, M.B., F.R.C.S.E.

Second Edition, large 8vo. Reprint. Cloth Boards. Illustrated. 6/-

THE PRACTICE OF HYPNOTIC SUGGESTION ; An Elementary Handbook for the Profession. By George C. KingsBURY, M.A., M.D.

8vo. Cofiously Illustrated. Io/6 net.

Illustrated with II2 Diagrams and Figures, most of which are original.

TESTS AND STUDIES OF THE OCULAR MUSCleS: By Ernest E. Maddox, M.D., F.R.C.S. Edin.

Second Edition. 69 Illustrations. Cloth, 8vo. $4 / 6$.

OPHTHALMOLOGICAL PRISMS and the Decentering of Lenses. A Practical Guide to the Uses, Numeration, and Construction of Prisms and Prismatic Combinations, and the Centering of Spectacle Lenses. By Ernest E. Maddox, M.D.

Demy 8vo. Bevelled Boards, Illustrated. 2/6.

EYE-SIGHT AND SCHOOL LIFE. By SIMEON SNELl, F.R.C.S. Ed., \&c. 
JOHN WRIGHT \& CO., Publishers and Printers, BRISTOL.

Second Edition. With numerons Plates and Iliustrations. 7/6 net. RHELMATOID ARTHRITIS; ITS PATHOLOGY, Morbid Anatony, and Treatment. By Gilbert A. Bannatyne, M.D., M.R.C.P.

$$
\text { Large 8vo, Cloth. 6\%. }
$$

EPITOME OF MENTAL DISEASES. A liook of Reference for Practitioners and Students, Alphabetically arranged. By James Shaw, M.D. With a short Appendlix; bringing the Legal forms up to date, 1897 .

$$
\text { Svo Cloth. I } 43 \mathrm{fH} \text {. Illustrated. 3/-net. }
$$

PULMONARY TUBERCULOSIS: Its Treatment and Cure. With Appendix concerning the British Congress on Tuberculosis Igor. By Carlo Ruata, M.D., Prof. of Mat. Medica in the Univ. of Perugia; and I'rof. of Hygiene in the Royal Agri. Inst. of I'erugia.

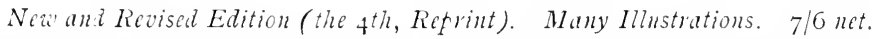

THE TREATMENT OF DISEASE BY PHYSICAL, METJUODS: Being the Third Edition of "Lectures on Massage and Electricity." Carefully Revised and in part Re-written, with additional matter. By Thos. Stretch Dowse, M.D., F.R.C.P. Edin.

Refrint. Pocket size, limp coners. With mumercus Illustrations. 2/-

MASSAGE PRIMER (For Learners.) By TiIOMAs Stretch Dowse, M.D.

2nd Ed. Refrint. 27 Iliustrations. Bewelled Boards, Cloth. 3/6 net

THE SWEDISH SYSTEM OF PHYSICAL EDUCATION: Its Nedical and General Aspects. Expanded from a Paper read before Nembers of the British Medical Association; with the addition of Twenty-seven Illustrations from Sketches by THEOdore Fisher, M.D. By Theodora Johnson.

\section{Crown 8io. Brards. 2/-net.}

DOCTOR AND PATIENT: Hints to Both. By Dr. Robert Gersuxy, Director and Principal Visiting Surgeon of the Rudolfinerhaus, Vienna. Translated, with the permission of the Author, by A. S. Levetus; with Preface by D. J. LeEch, M.D., F.R.C.I., \&c., Professor of Pharmacology in the Owens College and Victoria University.

"An admirable little work. . Will be found of great value to patients as well as medical men."-Lancet.

$$
\text { Second Edition. Crown svo. 2/6 net. }
$$

THE MEDICAL EXAIINATION FOR LIFE ASSURANCE, With Remarks on the Selection of an Office. By F. de Havilland Hall, M.D, F.R.C.P. 
tons

-

.

, 




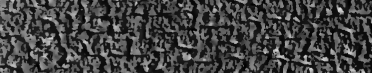

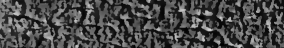

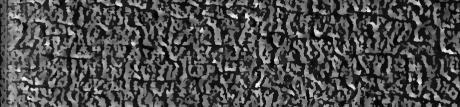

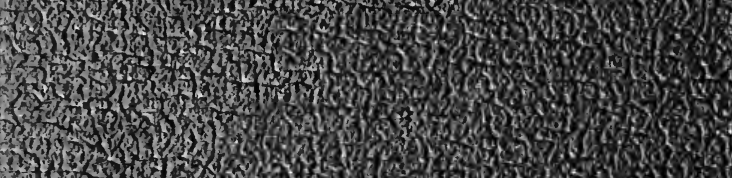

H.

3 .

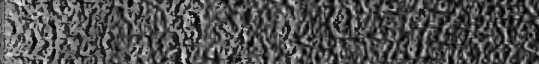

30.7 .

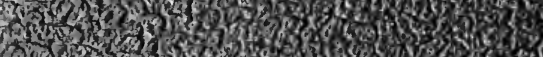

1.

W.

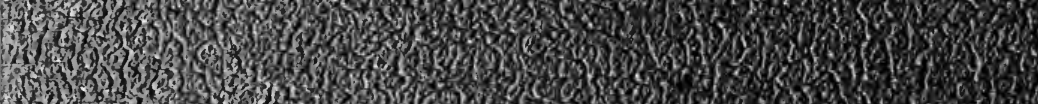

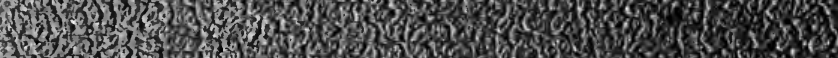

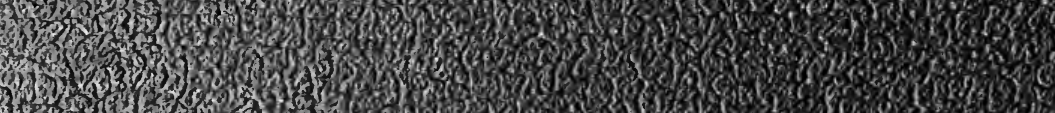

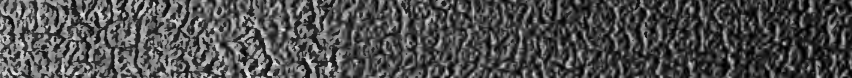

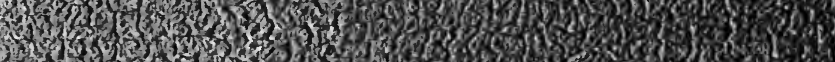

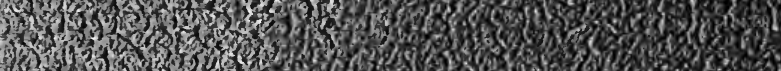

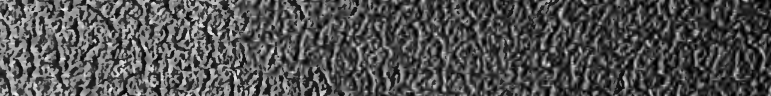

3
3

3.

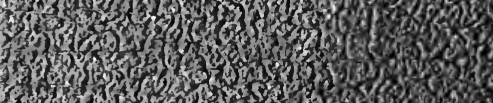

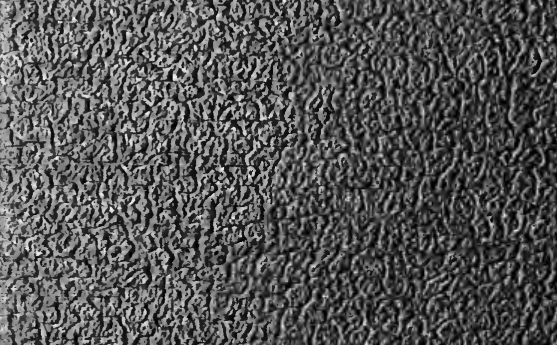

1.7.

13.

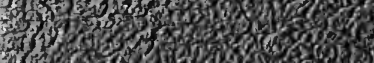

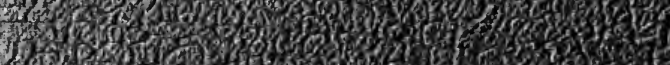

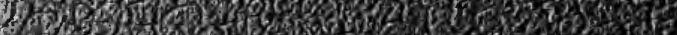

